\title{
EGFR-Ligand Signaling in Breast Cancer Metastasis: Recurring Developmental Themes
}

\author{
Nicole K. Nickerson ${ }^{1}$, Jennifer L. Gilmore ${ }^{1}$, Kah Tan Allen ${ }^{1}$, \\ David J. Riese II ${ }^{2}$, Kenneth P. Nephew ${ }^{1,3}$ and John Foley 1,3,4 \\ ${ }^{1}$ Medical Sciences Program, Indiana University School of Medicine, Bloomington, IN \\ ${ }^{2}$ Harrison School of Pharmacy, Auburn University, Auburn, AL \\ ${ }^{3}$ Indiana University Cancer Center Indiana University School of Medicine, \\ Indianapolis, IN \\ ${ }^{4}$ Department of Dermatology, Indiana University School of Medicine, Indianapolis, IN \\ United States of America
}

\section{Introduction}

\subsection{ErbB receptors, ligands and signaling}

Breast cancer affects nearly 1 out of 9 women worldwide. The quality of treatment for breast cancer has improved to the point that close to $80 \%$ of patients in countries with advanced healthcare delivery systems survive the disease (1). Yet over $20 \%$ of breast cancer patients succumb to the disease, and the majority of these have metastatic breast cancer cells that occupy and compromise the function of distal organs (1). There has been an intensive effort to improve treatments for metastatic breast cancer. Novel treatment strategies have arisen from the study of the molecular and cellular biology of breast cancer cell lines. These studies have produced a group of agents called targeted therapeutics because they are often directed at a single molecule rather than a general process such as DNA replication or cytoskeletal function. The ErbB family represents a target that is present in breast cancer. Therapeutics to ErbB2 have been used to treat aggressive breast cancer for over a decade with considerable success (2). However, therapeutics that primarily target the EGFR have not been used extensively in breast cancer, and there are some improved agents for the receptor that are just entering the clinic. Recent conclusions from studies of metastatic breast cancer suggest new possibilities for the use of EGFR therapeutics. This review will describe the members of the EGFR signaling family, discuss the cellular context in which they function in development, and correlate this with the biological role of these molecules in breast cancer metastasis.

\subsection{ErbB family members}

The ErbB family consists of 4 receptors: ErbB1 or more commonly called EGFR, ErbB2/ Her2, ErbB3 and ErbB4 (3). Signaling is generated when EGFR and ErbB4 bind to their ligands. In contrast, the ErbB2 extracellular binding domain fails to bind any of the 15 agonists, and in ErbB3 the kinase domain is not functional. Upon ligand stimulation, EGFR and ErbB4 receptors can transduce their signals as homodimers or heterodimers; however, 
the signal generation from ErbB2 or ErbB3 require heterodimerization with another ErbB family member (3).

The ErbB receptors are stimulated by 15 ligands but the situation is complicated because several of these agonists can bind more than one receptor. The EGFR exclusive agonists are epidermal growth factor (EGF), transforming growth factor alpha (TGF- $\alpha$ ), amphiregulin (AREG) and Epigen (Epi) (3, 4). ErbB4 is specifically bound and activated by Neuregulins (NRG) 3, 4, 5 (3, 4). Heparin-binding EGF-like growth factor (HB-EGF), epiregulin (EREG), and $\beta$-cellulin (BTC) bind and activate both the EGFR and ErbB4 $(3,4)$. NRG 1 and 2 binds both ErbB3 and ErbB4 and NRG 1 can bind the EGFR with low affinity $(3,4)$.

All of the ErbB agonists are synthesized as plasma membrane bound integral membrane proteins (5). In some cases, the transmembrane ligands stimulate ErbB signaling on adjacent cells through a juxtracrine mechanism which may mediate the stromal-epithelial interactions (6) (7). Most ErbB signaling requires proteolytic cleavage termed ectodomain shedding for the ligand to be released and available to bind receptors that may be on the same cell (autocrine signaling), or on neighboring cells (paracrine signaling) (5). The proteases that mediate the process are from the "a disintegrin and metalloproteinase " or (ADAM) family $(8,9)$. There are 40 members of the ADAM protein family that function in cell adhesion and ectodomain shedding. These ADAMs are integral membrane proteins in which the extracellular region contains a protease as well as a disintegrin domain that modulates integrin binding (9). ADAMs can be activated by a wide range of stimuli that signal through G-protein-coupled receptors and these signals are often transduced by Src (10). The shedding of AREG, EREG, HB-EGF, Epigen, TGF $\alpha$ and NRG $1 \& 2$ is typically catalyzed by the single family member ADAM 17, whereas BTC and EGF are cleaved by ADAM 10 (8). In addition, ADAM 17 cleaves many other cytokines, growth factors, receptors, adhesion molecules and extracellular matrix proteins, suggesting its activity may be a key determinate of cellular behavior (9). Nevertheless, emerging data suggest that EGFR ligands can be shed by other proteases such as the ADAM thrombospondin (ADAMTS) family that is structurally related to the ADAM family, but is secreted and the disintgrin domain is replaced by a thrombospondin domain that binds to matrix $(11,12)$. Also, it is likely that other metalloproteinases secreted from cells in a paracrine relationship are capable of releasing ligands (13).

Over the past two decades the expression of ErbB receptors, ligands, and their activating proteases in normal breast and breast cancers have been intensively studied. Various mRNA detection methods and immunohistochemistry studies have concluded that the entire ErbB family is expressed in various breast cancers. In fact, it appears the vast majority of the family is expressed in the mammary epithelia (14-16). Since newer therapeutics that target the EGFR are being considered for use in cases of advanced breast cancer, in the rest of this review we will focus on how this receptor is activated and describe its role in development and cancer progression.

\subsection{EGFR homodimer signaling}

EGF was the first ligand identified and due its abundance in the mouse salivary gland and relative ease of purification from this source (17). EGF has historically been used for receptor binding, signaling, trafficking, and cell fate studies resulting in a model of receptor signaling that is in many ways considered to be the prototype for receptor tyrosine kinases (18-20). The binding of EGF to the EGFR exposes the dimerization arm in the extracellular domain 
that permits interaction with another EGFR receptor or hetrodimerization with other ErbBs. Ligand binding also induces a conformational change in the receptor that activates the intracellular kinase domain, which in turn can phosphorylate tyrosine residues on the adjacent C-terminal tail of the dimerized ErbB receptor. The 10 phosphorylated tyrosine residues serve as docking sites for adapter proteins or other signal transduction components, resulting in activation of Ras, MAPK, src, STAT 3/5 and PLC $\gamma /$ PKC and the PI3 kinase-AKT-pro survival pathway. Activation of these signaling pathways by ErbB dimers has profound impact on proliferation, resistance to apoptosis, differentiation, as well as motility/migration associated behaviors. Not all tyrosine phosphorylation of EGFR Cterminal tail results in stimulation of downstream signaling pathways. For example, phosphorylation of the 974 residue triggers enodcytosis of the receptor, and phospho 1045 binds to $\mathrm{Cbl}$, mediating ubquitination of the receptor and subsequent proteosomal degradation $(4,21)$. Trafficking studies suggest that $\sim 50 \%$ of EGF stimulated EGFR is degraded, whereas the remainder is recycled back to the plasma membrane (22). Thus, activation of the EGFR by EGF directly stimulates a broad group of cellular signaling pathways, many of which converge on elements of the ERK/MAPK pathway (3), but this signaling is dampened by receptor turnover. The rapid turnover of the EGF stimulated EGFR is believed to limit stimulation of cellular proliferation, permitting a balance with various differentiation-inducing stimuli present in a normal tissue $(3,22,23)$. In cancers, autocrine EGFR homodimer signaling is substantially attenuated, shifting the cell fate balance towards proliferation and survival rather than differentiation, apoptosis and senescence.

\subsection{Attenuating EGFR signaling with heterodimerization}

Probably the most well understood attenuation of EGFR signaling occurs when the receptor heterodimerizes with the ErbB 2 receptor $(24,25)$. It is believed that EGFR heterodimerization with ErbB2 frequently occurs in a number of breast cancers $(26,27)$. Despite being unable to bind ligand, the ErbB2 dimerization arm is constitutively exposed, which allows this receptor to more efficiently dimerize with other liganded ErbB family members (4). The resulting ErbB2 containing heterodimers attenuate EGFR signal transduction in several ways (28-32). First, the affinity of this ErbB2 complex for ligands is enhanced. Second, the ErbB2 phosphotyrosine domains bind most adapter proteins with higher affinity than those of the ErbB homodimers, resulting in more efficient signal transduction. Third, ErbB2/EGFR heterodimers are slowly endocytosed, and are more frequently recycled to the plasma membrane than the EGF stimulated homodimers. By virtue of its strong interactions with adapter proteins and altered trafficking downstream of endocytosis, an EGFR/ErbB2 heterodimer can amplify and extend the duration of EGFR ligand signaling, leading to proliferation and survival at the expense of other cell fates (28-31).

In contrast to the fairly well established understanding of ErbB2 containing heterodimers, there have been few studies on the EGFR heterodimerized with ErbB4 or ErbB3. Co-immuno precipitation experiments have confirmed the presence of the ErbB4/EGFR in a lung epithelial cells and type II pneumocytes; however, the specific function of this complex was not determined $(33,34)$. Co-expression of ErbB4 and EGFR plasmids in model NIH 3T3 fibroblasts or $\mathrm{CHO}$ lines, provided evidence of dimerization of these receptors, and suggested that this complex could induce cellular transformation in the presence of EGF or NRG1. Further analysis of the CHO system found that the ErbB4/EGFR heterodimer 
specifically induced B-Raf kinase activity, which was speculated to induce transformation by increasing the activity of the ERK/MAPK pathway (35). Recently, ErbB3/EGFR heterodimers have been identified in pancreatic cancer cell lines $(36,37)$. It appeared that the ErbB3/EGFR complex may be a more effective stimulus of proliferation in pancreatic cancer cell lines than EGFR homodimers (36). Additionally, these studies suggest the ligand AREG is able to stimulate activity of the ErbB3/EGFR heterodimer $(36,37)$. Unfortunately, the comprehensive binding, signal transduction and trafficking studies completed for ErbB2 containing receptor complexes have not been completed for EGFR/ErbB4 or ErbB3 heterodimers. This information, coupled with the identification of the specific cell types and tumors that express heterodimers and the function of these complexes will be important considerations for expanded use of ErbB targeted therapeutics.

\subsection{Other EGFR ligands}

As studies of receptor binding, conformation, phosphorylation, and trafficking are completed for each ligand, it is becoming clear that each agonist induces signaling that can be viewed as a variation of the basic EGF-EGFR homodimer scenario. This attenuated signaling produced by each ligand has the potential to induce subtle differences in downstream signaling, which would be expected to result in altered gene expression and cellular behavior. In the preceding section, the emerging differences in signaling are detailed for each of the ligands that bind the EGFR.

\subsubsection{TGF $\alpha$}

Next to EGF, the most intensively studied ligand has been TGF $\alpha$. Similar to EGF, TGF $\alpha$ exclusively binds to and activates the EGFR. Binding studies suggest that TGF $\alpha$ binds to the receptor with similar affinity as EGF (32). However, conclusions from structural studies involving ligand-receptor complex data indicates there are subtle differences in the conformation of the extracellular ligand-binding domain (sub domain II) induced by TGF $\alpha$ as compared to EGF (4). It is unclear whether this conformational change induced by TGF $\alpha$ could generate alterations in EGFR kinase activity or accessibility of C-terminal tyrosines. Although not comprehensively studied at this point, some of our early studies with breast cancer cell lines suggest that TGF $\alpha$ does not induce the extensive receptor phosphorylation observed with mouse salivary gland derived EGF (Fig 1). Additionally, it has been long recognized that TGF $\alpha$ induces different trafficking of the receptor than EGF (38). Close to $100 \%$ of receptors internalized after TGF $\alpha$ treatment are recycled to the plasma membrane (22). At physiological $\mathrm{pH}$ of 7.4 in the extracellular environment, TGF $\alpha$ and EGF have similar binding affinities for the EGFR $(22,38)$. However, at $\mathrm{pH}$ close to 5 such as in the endosome, TGF $\alpha$ has decreased affinity for the $\operatorname{EGFR}(22,38)$. It appears that dissociation of the ligand from the EGFR in the endosome permits the receptor to be recycled back to the plasma membrane where it can be reengaged by ligand. It is thought that the three additional histidines found in the receptor binding domain of TGF $\alpha$ provide a greater sensitivity to $\mathrm{pH}$ for agonist-receptor interactions (38). In fact, mutations that add histidines to this region of EGF decreased ligand-receptor binding at low $\mathrm{pH}(39,40)$. Together, the altered ligand induced receptor conformation, phosphorylation and trafficking appear to result in TGF $\alpha$ being a more potent stimulator of proliferation of EGFR expressing cell lines than EGF. 


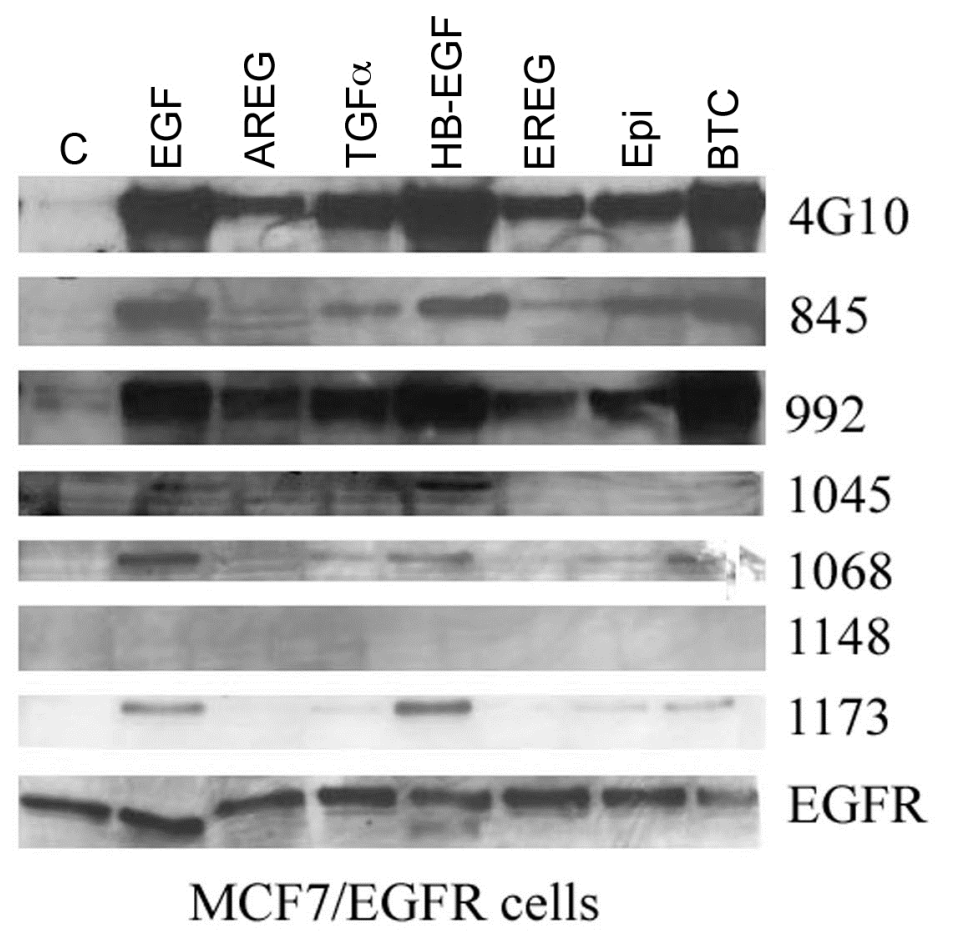

Fig. 1. EGFR phosphorylation after ligand stimulation.

The human breast cancer cell line MCF7 was engineered to overexpress high levels of the EGFR after retroviral transduction. Cells were grown to $80 \%$ confluence and placed on ice for 30 minutes. Ligands (R\&D, Minneapolis) were applied for 10 minutes to the media and then the media was removed, cells washed and proteins extracted. The EGFR was concentrated with Concanavalin A beads and extracted with Laemmli sample and applied to gels and western blotted with specific antibodies to phosphorylated tyrosines listed on the left. The various ligands used are listed on the top of the figure (C) represents vehicle treated cells.

\subsubsection{AREG}

The differential impact on breast cancer cell behavior that AREG exhibits compared to EGF has drawn considerable attention to the concept that various EGFR ligands have discrete functions (41-43). Among the ErbB receptors, AREG appears to exclusively bind and activate the EGFR. In addition, the ligand contains a heparin-binding domain N-terminal to the receptor binding region $(44,45)$. It appears that interaction with heparin-sulfated proteoglycans on the plasma membrane enhances the ability of exogenous AREG to activate the EGFR (46). What has been a matter of controversy has been the relative strength of AREG binding to the EGFR as compared to other ligands. The initial identification of human AREG by Shoyab and colleagues, reported the fully processed ligand isolated from breast cancer cells had reduced affinity for the human EGFR, as compared to salivary gland derived mouse EGF (44). In contrast, subsequent studies with human recombinant ligands 
found that AREG has similar affinity for the EGFR as EGF and TGF $\alpha(47,48)$. Inducing further complexity, additional analyses of ligand receptor interactions have suggested that recombinant AREG does not induce efficient dimerization of the EGFR, as compared to recombinant EGF and TGF $\alpha$ (49). Interestingly, proteolytic processing of AREG in mammalian cells may eliminate the C-terminal portion of the ligand binding domain that is required for high affinity for the receptor (50). In addition, the terminal portion of the receptor binding domain in all other EGFR ligands contains a leucine, whereas a methionine is found in AREG, and this is speculated to reduce affinity for the receptor (50).

More recent studies have focused on the distinct downstream signaling and cellular behavior induced by AREG. Unlike exogenous EGF treatment, AREG stimulation of model cell lines and breast cancer cell lines is unable to induce efficient phosphorylation of many of the tyrosine residues in the C-terminal tail of the $\operatorname{EGFR~}(22,43,51,52)$ and (Fig. 1). Notably, the $\mathrm{Cbl}$ binding 1045 tyrosine residue is not efficiently phosphorylated by AREG and this ligand fails to induce rapid turnover of the EGFR. Trafficking studies indicate that AREG liganded EGFR is rapidly internalized, but then is recycled back to the plasma membrane. In addition, AREG binding to the EGFR is very resistant to acidic $\mathrm{pH}$ suggesting that the ligand does not disengage in the endosome as does TGF $\alpha$ (22). It appears that AREG may be unique among the ligands in that it induces EGFR trafficking through Rab 4 and Rab 11 containing endosomes $(22,43)$. AREG induces prolonged phosphorylation of ERK relative to EGF $(41,52)$. This altered signaling appears to be the basis of AREG stimulating the loss of cell-cell adhesion and increase motility/migration associated behaviors in breast and other epithelial cells $(41,53)$. AREG overexpression has also been found to selectively activate interleuken-1 induced NFK $\beta$ signaling in breast epithelial cells (41-43).

\subsubsection{Epigen}

This was the last ErbB family member identified in 2000, and it has not been as intensively studied as other ligands. The ligand activates the EGFR and does not activate ErbB3 or ErbB4 when these receptors are expressed in isolation $(54,55)$. However, epigen can activate ErbB4 and ErbB3 when these receptors are co-expressed with ErbB2 $(54,55)$. Epigen appears to have $\sim 100$ fold less affinity for the EGFR relative to recombinant human EGF. Not surprisingly, we found that epigen induced modest phosphorylation of breast cancer cells (Fig. 1). The binding of epigen to the EGFR appears to be sensitive to $\mathrm{pH}$ similar to TGF $\alpha$. Modeling suggests that additional histidines in the receptor binding domain are responsible for the dissociation of the ligand from the EGFR at low $\mathrm{pH}(54,55)$. In comparison with EGF, epigen induced significantly weaker ubiquitylation and degradation of EGFR, and once internalized, it appears that the receptor is efficiently recycled to the plasma membrane. As expected for lower affinity ligands, epigen is a more potent mitogen than EGF and displays prolonged MAPK signaling $(54,55)$.

\subsubsection{HB-EGF}

Exogenous HB-EGF is a high affinity ligand for the EGFR but it also binds and activates ErbB4 (32). Exogenous HB-EGF does not as robustly stimulate phosphorylation of ErbB4 as it does the EGFR (56). In addition, pro-HB-EGF serves as the diptheria toxin receptor in human cells (6). Similar to EGF, exogenous HB-EGF induces extensive EGFR tyrosine phosphorylation in most cell types studied $(22,56)$, and we found this to be the case for breast cancer cells (Fig. 1). Upon binding to and activation by HB-EGF, the EGFR is rapidly 
endocytosed and the majority of ligand engaged receptors are trafficked to lysosomes and degraded (22). The binding of HB-EGF to the EGFR was resistant to low $\mathrm{pH}$. HB-EGF shows similar effects on cell proliferation and migration to those exhibited by EGF (57).

As its name implies, HB-EGF has a heparin-binding region $\mathrm{N}$-terminal to the EGF domain. This domain has been shown to interact with heparin sulfated plasma membrane proteins such as the tetraspanin, CD9 and the extracellular matrix binding/cell differentiation marker protein CD44 $(6,57)$. In particular the heparin-mediated interaction between HBEGF and CD9 appear to be crucial to juxtacrine signaling by the proligand (58). Finally, the associations between the heparin binding domain and cell membrane associated heparin sulfated proteoglycans appear to be crucial to localizing HB-EGF to regions of cell-cell contact. Furthermore, the interaction with these heparin-sulfated proteoglycans prevented proteolytic cleavage of the pro-ligand, whereas exogenous heparin increased shedding of HB-EGF $(7,58)$. In contrast to the impact of shed ligand, juxtacrine signaling by the pro HBEGF appears to be antiproliferative (58).

\subsection{5 $\beta$-cellulin}

Exogenous $\beta$-cellulin is a high affinity ligand for the EGFR and ErbB4 (32). In general, exogenous $\beta$-cellulin phosphorylates the EGFR to a similar extent as EGF in model cell types, and this is what we observed with breast cancer cells (Fig. 1) $(22,59)$. This exogenous ligand also stimulates total ErbB4 phosphorylation to an extent similar to NRG1, but there may be differences in phosphorylation of specific tyrosine residues (60). Upon binding to and activation by $\beta$-cellulin, the EGFR is rapidly endocytosed and trafficked to lysosomes where the majority of it is degraded (22). The binding of $\beta$-cellulin to the EGFR was resistant to low $\mathrm{pH}$. Exogenous $\beta$-cellulin was slightly less efficient than EGF at inducing proliferation in some specific cell types (60). There have been some reports that $\beta$-cellulin binds to heparin and may participate in juxtacrine signaling (61).

\subsubsection{EREG}

Unlike the other dual receptor ligands HB-EGF and BTC, EREG is a low affinity ligand for the EGFR (32). EREG typically induces much less phosphorylation of the EGFR than EGF in model cell lines (62-65). In breast cancer cells, we found that the epiregulin induced phosphorylation of the various tyrosines on the EGFR to an extent similar to AREG and the low affinity ligand epigen (Fig. 1). EREG is not as effective as NRG or BTC in stimulating ErbB4 phosphorylation (62-65). The ligand appears to preferentially activate heterodimers and efficiently induces EGFR heterodimers with all three other receptors (65). Upon binding to and activation by EREG, the EGFR is rapidly endocytosed, but then is recycled back to the plasma membrane, and its binding to the receptor was resistant to low $\mathrm{pH}(22)$. Exogenous EREG was more efficient than EGF at inducing proliferation in some cell types $(63,65)$. Also EREG does not induce as great of activation of the MAPK pathway as EGF, but the duration of MAPK phosphorylation was increased relative to the prototype ligand $(63,65)$.

Thus, the expression of specific EGFR ligands could influence the progression of breast cancer in several ways. First, three of the ligands (HB-EGF, BTC and EREG) could induce ErbB4 signaling on breast cancer cells themselves or their microenvironment, whereas the other 4 ligands EGF, TGF $\alpha$, AREG and epigen would only induce EGFR signaling. Second, if juxtacrine EGFR signaling between breast cancer cells may require interaction with heparin sulfate proteoglycans, only HB-EGF and AREG would be likely mediators of this signaling. 
Juxacrine EGFR signaling might be antiproliferative and also only occur in breast cancer that lacked active sheddases that released HB-EGF and AREG. Third, EGFR signaling induced by soluble ligands appears to be dependent on the relative ratio of receptor degradation versus recycling to the plasma membrane. For example, those ligands whose binding leads to rapid receptor degradation (EGF, HB-EGF and BTC) would activate high levels of downstream signal transduction, but this would likely be of short duration. In contrast, the ligands that induce recycling of the internalized receptor to the plasma membrane would produce longer duration EGFR signaling. In the context of autocrine signaling in breast cancer cells, the longer duration EGFR signaling is likely to more efficiently induce mitogenesis. What remains to be determined is whether the duration of EGFR signaling differentially impacts other cellular behaviors relevant to breast cancer progression such as resistance to apoptosis, and the stimulation of invasive/motile behaviors. Finally, in the context of paracrine signaling it is not clear how EGFR turnover influences the supportive functions of stromal and immune cells of the tumor microenvironment.

\section{EGFR/ErbB signaling in development}

\subsection{ErbB signaling and mammary gland development}

The majority of research on mammary gland development is performed in the mouse model due to its biologically and histologically similarity with humans, and the power of transgenic knockout murine models (66). Embryonic mammary gland development in the mouse begins around embryonic day 10.5 (E 10.5), where bilateral milk lines are formed from front to hind paws. Between E11.5 and E12.5, five placodes on each milk line develop with eventual epithelial bud formation at each placode. These epithelial buds remain quiescent until E15.5, where minor branching permits the migration of mammary epithelia into the fat pad, and mesenchymal differentiation forms the overlying nipple epidermis. This rudimentary mammary gland will remain quiescent until after birth (67). The majority of mammary gland growth and development occurs in postnatal life during puberty and pregnancy, and ErbB signaling impacts this phase.

The primary hormone that drives post-natal mammary gland development is the nuclear steroid hormone, estrogen. Estrogen stimulates proliferation of luminal cells within the mammary ducts, causing ductal elongation and branching (68). Progesterone also increases cellular proliferation of the mammary ducts, and acts synergistically with estrogen during periods of high hormone levels such as pregnancy (68). Prolactin, a non-steroid hormone released from the pituitary gland, is active in mammary gland development, late in pregnancy, stimulating alveolar development and triggering milk production during lactation (69).

The mouse mammary gland begins pubertal outgrowth between 3-4 weeks of age, and is complete at 8-12 weeks of age. The gland requires both longitudinal ductal growth, as well as ductal branching to fully infiltrate the mammary fat pad. Pubertal growth is directed by the cells within structures called terminal end buds (TEBs), which are a bulbous expansion of the epithelia. The TEBS are found at the distal end of each growing duct, and consist of 3 to 4 cell layers, including cap cells that make up the 'basal' layer and multiple layers of interior luminal-like body cells that line the duct. Signaling within the cells of the TEBs and the surrounding stroma will determine the extent of continued ductal branching (70) (71). From this point, the mammary gland will show minimal growth with each estrous cycle. Upon pregnancy, estrogen and progesterone drive another large spurt of growth resulting 
in extensive ductal branching. Progesterone also works with prolactin to signal differentiation of the secretory or alveolar cells throughout the duct system, which produces the large volumes of milk post parturition $(72,73)$. Termination of lactation will eventually lead to involution, where large-scale apoptosis will eliminate the secretory alveoli and remodel the remaining ducts of the mammary gland, returning the structure to a state similar to that of the virgin gland.

\subsubsection{Role of EGFR in mammary gland growth}

In virgin mice, EGFR, ErbB2, and ErbB3 are present in the developing ductal structure while there is minimal ErbB4. During pregnancy, this pattern changes to greatly increase expression of ErbB4 in the mammary epithelium, while ErbB4 levels will again regress during lactation and involution (74). Even though three of the receptors are present during growth, there is minimal ErbB phosphorylation observed until ductal morphogenesis begins. During pubertal growth, phosphorylated EGFR and ErbB2 are detected, which suggested that these receptors may mediate the impact of estradiol (E2) on the gland (75).

The EGFR-/- mice die within 8-days after birth and show a wide range of dysfunctional epithelia, but their mammary glands were similar to their wild-type littermates. Transplantation of pre-pubertal glands from EGFR-/- mice into cleared fat pads of wild-type littermates failed to infiltrate the structure, but glands from wild-type mice produced normal ductal systems (76). In contrast, when a purified mammary epithelium from the EGFR $/$ - mouse was implanted into cleared fat pads with mammary stroma from wild-type mice it produced a normal ductal tree, whereas the opposite combination of wild-type epithelium and EGFR $/$ - stroma failed to penetrate the fat pad. Thus, postnatal mammary ductal growth is dependent on the presence of the EGFR in mammary stromal fibroblasts. It appears that signaling by the receptor triggers the production of stromal growth factors important to TEBs in ductal elongation (76).

The EGFR ligands EGF, TGF $\alpha$, and AREG, are found in different locations within the TEB during ductal growth. Using immunohistochemical techniques, TGF $\alpha$ is found exclusively in the basal cap cell layer while the luminal cells express only EGF (70). AREG has been found in both the basal cap cells and the luminal cell layers of TEBs (77). Luekette and colleagues produced knockout mice for each of these ligands separately or as double and triple knockouts. While all three mice null for the individual ligands and their various crosses were fertile, not all had distinct mammary phenotypes. Double-knockout mice for EGF and TGF $\alpha$, but which contained AREG, displayed normal ductal growth and TEB formation. Mice that were single-knockout for AREG or a triple-knockout for all ligands displayed almost a complete lack of ductal growth into the fat pad at 8-12 weeks (78). In the AREG-/- mice, mammary epithelial failed to fill the fat pad even after multiple pregnancies, strongly suggesting that AREG-EGFR signaling mediated the impact of estrogen on mammary ductal growth. This suggests that EGF and TGF $\alpha$ are dispensable for mammary gland growth, while AREG plays a vital role in glandular development. Recombination grafts indicated that estrogen stimulated pubertal mammary gland growth will not occur without AREG signaling to the stroma (79). The AREG gene is regulated by estrogen receptor alpha $(E R \alpha)$, which apparently accounts for its requirement in postnatal mammary gland development $(80,81)$. Whether there are any ligand specific effects of the AREG ligand in mammary development have not been explored. 
Studies performed with mice deficient for ADAM-17 have shown cardiac insufficiencies, a constellation of epithelial defects and die soon after birth similar to the phenotype of EGFR /- mice. The ADAM17-/- mice have small, immature mammary glands with minimal branching or ductal growth (82). To verify the requirement of ADAM-17, the defective growth of ADAM-17-null mammary epithelia can be rescued in the presence of exogenous AREG, EGF, or TGF $\alpha$ (82). In conclusion, estrogen induced growth of the mammary pad requires mammary epithelial cell ADAM-17 to shed AREG which then, is necessary to stimulate EGFR signaling in the stromal fibroblasts.

\subsubsection{Breast epithelial stem cell and ErbB signaling}

Potential mammary gland stem and progenitor cells have been identified using a series of methodologies used to identify the hierarchy of cells that produces that mature hematopoetic system. A single human mammary gland stem cell has been shown to regenerate all the cellular components of the human mammary gland, as well as produce milk proteins in immunocompromised mice (83-86). This work, coupled with mouse work has given rise to an epithelial hierarchy illustrated in figure 2. In this hierarchy, the mammary stem cells give rise to " the common or bipotent" progenitor; the bipotent progenitor gives rise to a luminal progenitor, as well as a cell type that gives rise to mature myoepthelial cells; and the luminal progenitor produces derivatives that ultimately differentiate into mature duct and alveolar cells (83-86).

The reproducible isolation of stem and progenitor cells from mammary epithelia has permitted profiling the various cell types for the expression of the receptors involved in post-natal mammary gland growth and breast cancer progression (85). The subpopulation containing putative mammary multipotent stem cells appear to lack expression of estrogen and progesterone receptors, whereas the EGFR is expressed in $\sim 12 \%$ of this fraction. Nearly $50 \%$ of the luminal progenitor inclusive population expressed high levels of EGFR. The relatively small subset of the differentiated luminal cell segment (ductal and alveolar cells) express the EGFR (83-86). Of possible significance is that both the mammary stem cell and luminal progenitor population are routinely propagated in a media supplement containing EGF. Whether this implies that propagation of these stem and progenitor cells are dependent on EGFR signaling or simply that there is a requirement for generalized receptor tyrosine kinase activity remains to be determined.

Taken together, the post-natal development of the mammary gland is regulated in large part by the EGFR. EGFR signaling in stromal fibroblasts is required for the estrogen-stimulated invasion mammary epithelium into the stromal fat pad that establishes the adult virgin mammary gland. It appears that the stromal EGFR signaling is mediated primarily by the estrogen-controlled ligand, AREG. Interestingly, the EGFR and its ligands are expressed in the mammary epithelia, but the recombination experiments suggest that autocrine receptor activity in this compartment is dispensable for the establishment of the adult mammary gland. At this time, it is not clear if autocrine EGFR signaling in a mammary epithelial stem or progenitor cells might be required for maintenance of the organ throughout adult life.

\subsection{EGFR signaling and cardiac development}

Careful reexamination of the EGFR-/- mice along with observations from the Waved-2 mice (these express a mutant form of the receptor with only $10 \%$ kinase activity) found defective 
Breast Cancer Subtypes

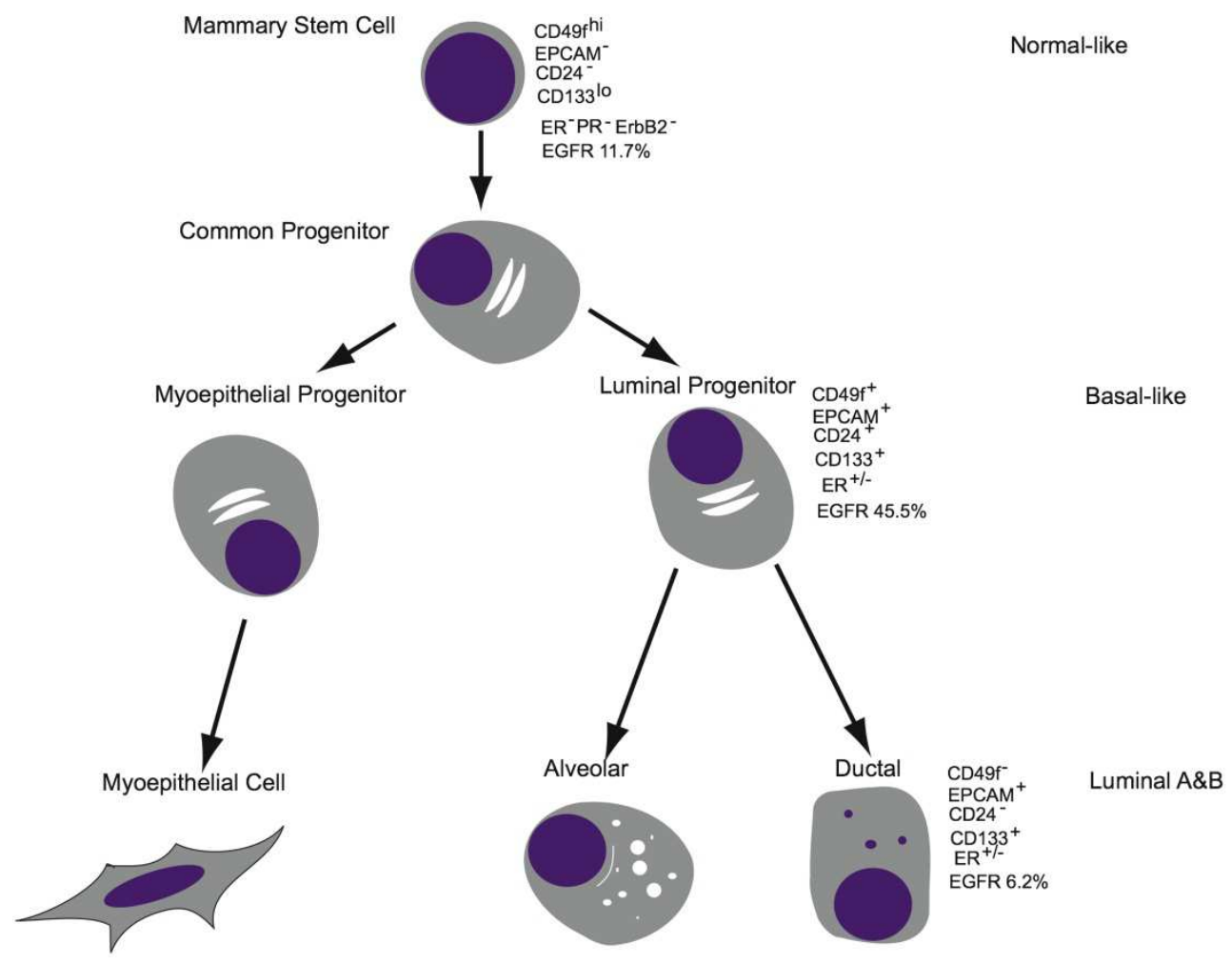

Fig. 2. Hierarchy of mammary epithelial cells.

The various cells of the mammary epithelium and their relationships are represented. To the right, is the expression pattern of the various cell surface markers. Below this is the ErbB and ER $\alpha$ expression along with breast cancer cell types the various cells are related to.

cardiac valve morphogenesis and maturation (94, 96). HB-EGF KO mice also exhibit defective maturation of cardiac valves, suggesting that this may be the relevant ligand that induces EGFR signaling in this process. Also, the HB-EGF-/- cardiac defect was phenocopied in the ADAM-17, suggesting that this protease released the ligand during cardiac development (97). 
In the context of cellular behaviors, it appears that the EGFR signaling system plays a role in differentiation. In the EGFR, HB-EGF and ADAM-17 KO mice which have hyperplastic valves it appears that the impact of this signaling is distinct from a proliferation and migration defect observed with the other ErbB knockouts. It is thought that HB-EGF-EGFR signaling decreases BMP expression, the factor which drives cardiac valve maturation, and hence is a differentiation factor (97).

\subsection{EGFR signaling and nervous system}

In the mouse, EGFR is highly expressed during brain development (E-7 to E-17) and is present on multipotent precursors of both neurons and glia, as well as developing astrocytes and some neurons $(98,99)$. The initial reports of the EGFR knockout did not identify a nervous system defect. However, reexamination of the KOs with extended post natal survival due to breeding of the knockout allele onto other mouse strains was able to identify brain defects (98). Among the defects identified were smaller or thinner forebrain regions, including the cerebral cortex, olfactory bulb and neocortex (98). Both HB-EGF and TGF $\alpha$ are expressed in portion of the fore brain during late embryonic and early postnatal life (98, 100). Modest histological defects were observed in the prefrontal cortex of mice with a conditional $\mathrm{KO}$ of HB-EGF in the forebrain, and these mice displayed behavior and defects in dopamine metabolism that have been observed in schizophrenia (98).

The defects observed in the forebrain of the EGFR-KO mice appear to result from disruption of the cellular interactions required to support neurons. There was substantial neuronal apoptosis in the early postnatal forebrain regions affected (98). However, this occurred in EGFR-expressing and non-receptor bearing neurons. In addition, there was a delay in the appearance of glial fibrulary acidic protein (GFAP) positive astrocytes in the glial limitans and white matter tracks of the fore brain. Although EGFR ligands can stimulate both the proliferation of astrocytes and recruitment of these cells from multipotent precursor cells, the major defect of the knockout mice appears to have a defect in the migration these glial cells from germinal centers. It is speculated that the delay in formation of contacts between neurons and astrocytes results in a deficiency of trophic support, resulting in neuronal cell death in the forebrain $(98,99)$.

EGFR expression is high in developing astrocytes, but the receptor is not present in mature astrocytes of the healthy adult brain. Upon injury or disease, EGFR expression is up regulated in reactive astrocytes (101). Reactive astrocytes lengthen processes produce plasma membrane pseudopodia and increase expression GFAP in response to all forms of CNS injury or disease (102). Stimulation of the EGFR on reactive astrocytes results in the upregulation of motility chemokines and extracellular matrix remodeling genes that are likely to contribute to glial scarring (101). Intriguingly, the use of EGFR tyrosine kinase inhibitors reduced nerve loss and lead to greater nerve fiber regeneration in optic nerve crush a model of a glial scarring (101). Thus, EGFR signaling in astrocytes facilitates neuronal survival during development, but receptor activity in reactive astrocytes actually contributes to neuron loss in pathologies.

\subsection{EGFR signaling and bone}

Bone phenotypes had not been reported in the original characterization ErbB receptor $\mathrm{KO}$ mice. However, work on the problem of malignancy-associated hypercalcemia had long established that TGF $\alpha$ increased the formation of bone resorbing osteoclasts in bone marrow 
cultures and whole animals $(103,104)$. The EGFR is expressed on both chondrocytes and cells of the osteoblast lineage in animals and humans (105). However, the function of the receptor was not established until a human EGFR gene-knockin mouse was created (106). This human EGFR transgene had a limited expression in mouse tissues that normally express the receptor, probably due to the presence of the Neo gene in the first intron of the construct. The human EGFR was expressed in the heart and nervous system and provided a rescue of the murine EGFR KO, but the receptor was not expressed in epithelia and bone. The human EGFR knockin mice were growth retarded and the skeletal phenotype appeared to be largely due to premature hypertrophy of the growth plate cartilages. Although routine histology did not reveal defects in the bones, growth of the knockin osteoblasts in vitro resulted in the increased formation of calcified nodules, which represent the end point of differentiation for these cells. Thus, in both cartilage and bone, EGFR signaling inhibits differentiation and helps maintain chondrocytes and osteoblasts in a proliferative state. At this point, it is unknown if any other ErbB receptors play a functional role in bone development or physiology.

Further insight into the role of EGFR in bone resulted from a study of global changes in osteoblast gene expression induced by the main serum calcium regulator, PTH. Activation of the PTH receptor on osteoblasts rapidly upregulates AREG mRNA expression 10 to 20fold, as well as increasing the TGF $\alpha$ and HB-EGF ligands $(107,108)$. In addition, PTH signaling induces shedding of ADAM-17 controlled ligands in the kidney (109). Further experiments indicated that addition of exogenous AREG to osteoblasts stimulated their proliferation. However ligand-EGFR signaling also inhibited osteoblast differentiation and dramatically decreased mineralization of osteoblast cell lines. Consistent with the role for AREG in stimulating the proliferation of osteoblasts, 4-week-old AREG-knockout mice exhibited less trabecular bone in the tibia than wild type littermates (107). These experiments suggested that EGFR signaling may mediate the impact of PTH on the recruitment and expansion of cells committed to the osteoblast lineage, but excessive signaling by this system could prevent these cells from undergoing terminal differentiation and forming mineralized bone. The inhibition of osteoblast differentiation and subsequent mineralized bone matrix deposition by-EGFR signaling may contribute to the uncoupling of bone formation from the accelerated bone resorbtion

\section{EGFR and breast cancer}

\subsection{ErbB and EGFR expression in primary tumors}

The development of platforms capable of simultaneously evaluating gene expression from a large portion of the genome have lead to identification of gene expression profiles that correlate with various established and some novel classes of breast cancer. These profiles have produced further insights into the impact of ErbB family members in breast cancer progression. Based on these studies, breast cancers are now divided into the following subclasses: ErbB2 amplified, luminal A, luminal B, normal breast-like, and basal (110-112). The ErbB2 amplified, basal and luminal B subtypes had substantially worse prognosis than the normal breast-like and luminal A.

\subsubsection{ErbB2 amplified tumors}

Among the molecular subclasses of breast cancer, the ErbB2 amplified, has the most well established functional role for an ErbB member in disease development and progression. The ErbB2 amplified tumors typically express ErbB3 and cell line experiments suggest the 
ErbB2/ErbB3 heterodimers stimulate proliferation of these cells through the PI3 kinase-AKT pathway (113). Despite the identification of the ErbB2 co-receptor, the precise ligand activating the ErbB3 has not been established. In addition, the correlation between high ErbB2 expression and poor prognosis suggests that ErbB2 contributes to metastasis and how the receptor contributes to these processes, is still under investigation (110-112).

\subsubsection{ER+ tumors: luminal $A \& B$}

Luminal A tumors express ER $\alpha$ along with GATA binding protein 3, X-box binding protein 1, trefoil factor 3, and other estrogen-regulated genes and high levels of the luminal keratins K8 and 18 (110-112). Luminal B tumors tend to express the above markers at slightly reduced levels, but have an upregulated cassette of genes, including proliferation related genes such as $\mathrm{Myb}$ and components involved in DNA replication. There is no specific ErbB family member included in luminal A or B signature. Further evaluations of $\mathrm{ER} \alpha+$ tumors have indicated that the majority of these tumors lack ErbB2 and EGFR expression, but close examination of data from microarray and PCR studies suggest there are occasional luminal type tumors that express these receptors $(16,110$ 112). A large fraction of ER $\alpha+$ tumors also contain ErbB4 (110-112), and there is some indication this receptor may be involved in a reciprocal regulatory loop with ER $\alpha$ signaling (114). Surprisingly, AREG was not in the original gene set that defined ER $\alpha+$ luminal tumors. A follow up interrogation of data that was used to relate disease outcome to cancer subclasses identified a correlation between higher levels of AREG expression, $\mathrm{ER} \alpha$, and the luminal A subclass (115). Also, this analysis indicated that ADAM-17 levels were low in the luminal A class relative to other tumor subtypes. These observations suggest that although most ER $\alpha+$ luminal A breast cancers express AREG, they lack the EGFR; therefore, autocrine signaling by this ligand receptor system should not be present in most of these tumors. Because the tumor cells express low levels of ADAM-17 it is unclear whether AREG could even participate in paracrine signaling between luminal A breast cancer cells and the tumor stroma. There is a possibility that other proteases produced by the tumor cell or microenvironment lead to shedding of AREG by luminal A breast cancers but whether this signaling impacts progression is unclear.

\subsubsection{Normal-like breast cancers}

The gene expression signature of these tumors clustered with the normal breast samples. These tumors had a signature that was not associated with epithelial cell types. They instead express high levels of collagen receptors, lipoprotein lipase and glycerol-3-phosphate dehydrogenase normally found in stromal cells or adipocytes. High levels of AREG and moderate levels of ADAM-17 were observed in occasional samples from this group of tumors, but the EGFR was absent. At this time there is no evidence that ErbB signaling plays any role in the biology of these tumors (110-112).

\subsubsection{Basal tumors}

These tumors lack the expression of the estrogen, progesterone and ErbB2 receptor-for this reason they are often called triple receptor negative tumors-and these cancers express some markers consistent with the myoepithelial cells that are in contact with the basement membrane. These tumors express high levels of the epithelial markers kertatin 5 and 14 (basal keratins), P cadherin as well as troponin (110-112). Basal breast cancers are correlated 
with poor survival, high rates of distant metastasis and are generally high grade, large tumors. Once the category became established, antibody labeling studies indicated that 50 to $70 \%$ of the basal cancers expressed high levels of EGFR immunoreactivity (116). Low levels of EGFR expression is correlated with reduced numbers of distant metastasis (117). These tumors also frequently express elevated levels of TGF $\alpha$ and ADAM-17 (115).

Within basal breast cancers there could be a fraction that exhibits autocrine TGF $\alpha$-EGFR signaling. The correlation of ADAM-17, TGF $\alpha$ and EGFR with poor prognosis implicates some role for this signaling system in metastasis. At this time, functional testing of TGF $\alpha$ in basal breast cancer models has not been completed. One major question that remains is: does TGF $\alpha$ participate in autocrine tumor cell signaling or paracrine tumor-stroma interactions. Future studies will identify which prometastatic cellular behaviors are activated by TGF $\alpha$-EGFR signaling, providing insight into whether receptor-targeted therapeutics might provide benefit in a metastasis prevention paradigm.

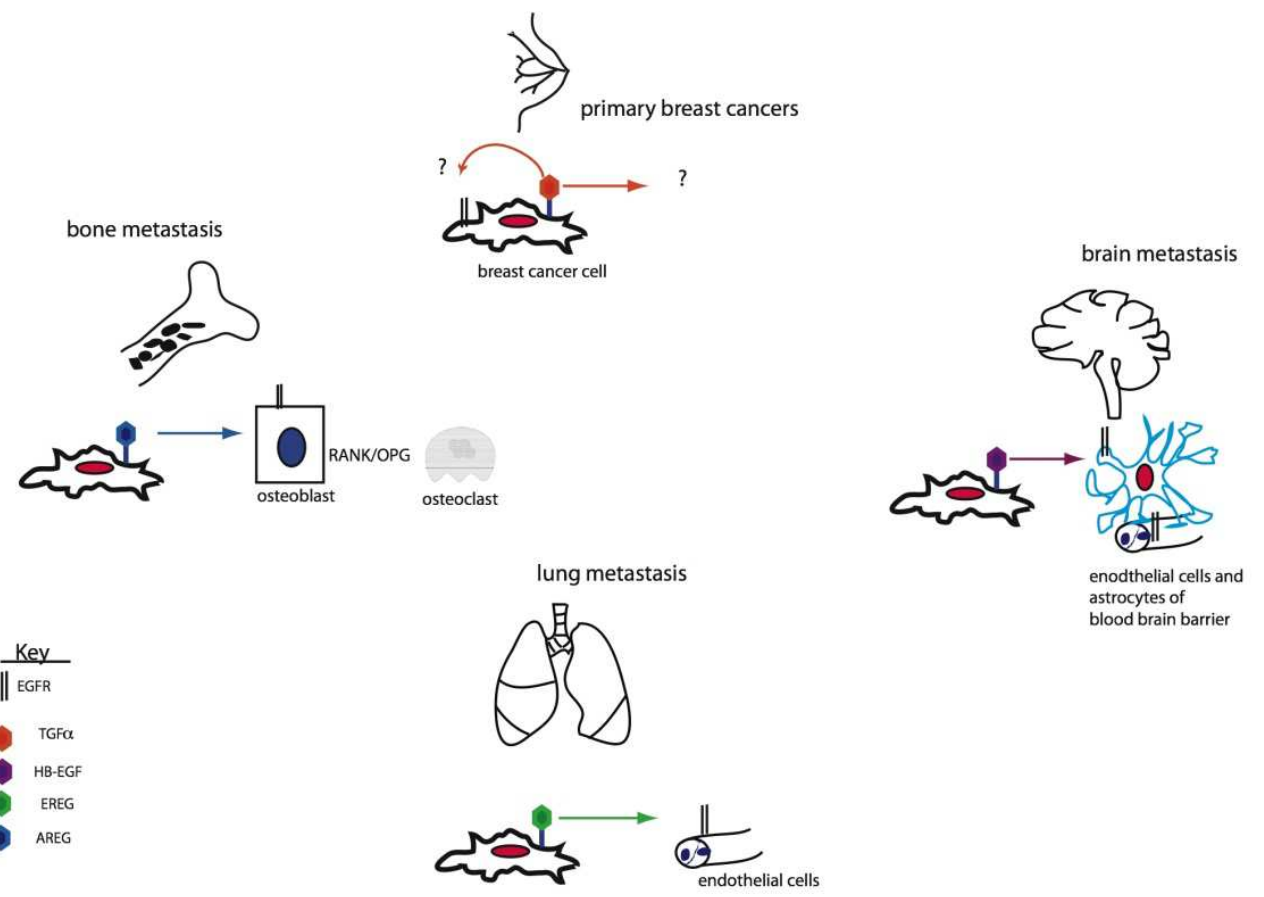

Fig. 3. Summary of EGFR-ligand signaling in models of basal breast cancer metastases. The specific ligand involved in primary tumors and metastatic site are indicated by the colored hexagons. The cell type that responds to the signal is also indicated. Paracrine signaling interactions appear to be important to metastases, whereas the relative role of autocrine versus paracrine signaling has not been explored in primary basal breast cancer.

\subsection{ErbB signaling in breast cancer metastasis}

Metastasis requires a set of cellular behaviors that are distinct from primary tumor formation. To spread from the site of the primary tumor to distant organs cancer cells must: 
1) move out of the primary tumor and invade through local connective tissue; 2) enter capillaries (intravasation); 3) survive in the blood stream; 4) exit the blood stream (extravasation) and invade into a new organ; 5) survive in the new organ possibly as a micro metastasis; 6) adapt to the new organ and grow as a macrometastasis (virulence) $(118,119)$. These steps can be viewed as two generalized processes: 1) invasion, which is movement of cancer cells through normal tissue and entry into the blood stream, and 2) colonization, which is escape from the blood stream and growth in a distant organ. Substantial progress is being made in identifying metastasis genes that mediate these generalized steps of the process. Metastasis genes are thought dispensable for primary tumor initiation and growth, but are crucial to the novel processes involved in the spread of cancer (119). In general, genes that facilitate invasion for carcinomas such as breast cancer are associated with EMT. Some of the genes involved in invasion are expressed in primary tumors. Colonization is considered to be the most inefficient part of the metastatic process and the growth of a cancer cells in a novel organ is likely to require novel changes in gene expression. Thus, the expression of colonization/virulence-associated metastasis genes are thought to be limited tumors within the specific target organ, rather than being present in most primary tumors $(118,119)$. Due to less availability, comprehensive gene expression studies of metastases have lagged behind the studies of primary tumors. As a result, alternative strategies for identifying gene signatures that are functionally involved with metastasis have been developed. For breast cancer metastases, Massague and colleagues selected in vitro various subclones of the aggressive breast cancer cell line MDA-MB-231. They found that many of the subclones had differing capacities to colonize various organs after intracardiac injection into mice $(12,119-123)$. Gene expression profiles were generated from the subclones that colonized specific organs, and these were compared to signatures from subclones that colonized the other organs. These signatures were then compared to larger data bases generated from human primary tumors that had ultimately metastasized to the organ of interest producing a refined signature. Subsequent functional analysis of these gene signatures has resulted in the identification of specific EGFR ligands as breast cancer metastasis genes.

\subsubsection{EREG and lung metastases}

The identification of a lung metastatic signature was derived from subclones of the MDAMB-231 (LM) breast cancer cells that produced lesions in the lung after intracardiac injection. Among the genes that emerged from this analysis was the ErbB ligand, EREG (121, 123). Knockdown of EREG alone failed to slow the growth of LM as primary tumors in the mammary fat pad or in lung. However, knockdown of EREG in conjunction with cyclooxigenase 2 (COX2), MMP1 and MMP2 (these genes had also been identified as upregulated in the LM signature) had a dramatic impact on both primary tumor growth and subsequent metastasis to lungs. The decreased primary tumor growth in the cells with reduced levels of EREG, COX2, MMP1 and MMP2 appeared to result from reduced angiogenesis. The LM cells recruited abundant dilated tortuous and leaky blood vessels, and the repression of these 4-genes resulted in reduced capillary branching, length and dye effusion. However, VEGF levels were not reduced in the quadruple knockdown tumors relative to controls. Also, no differences were observed in pericyte recruitment to the capillaries between the LM cells and the quadruple knockdowns, suggesting that capillary defects were the result of altered endothelial cell behavior. Also, these multiple knockdowns 
exhibited reduced ability to colonize lungs after intravenous injection as compared to the parental LM cells. Close evaluation of the lungs of animals injected with the quadruple knockdown cells found abundant cells trapped in the vasculature, suggesting a failure in extravasation. The deficiencies in quadruple knockdown extravasation were also observed with an in vitro assay. Consistent with the knockdown studies, single therapeutic agents that targeted EGFR (such as cetuximab, an EGFR blocking antibody), COX2 (celecoxib) or MMPs (GM6001) also had modest impact on behavior of the LM cells grown as primary tumor and their spontaneous metastases to the lung. However, combinations of two agents slowed the growth of primary tumors and reduced subsequent lung colonization. The efficacy of cetuximab suggests that EREG is stimulating this the EGFR and not ErbB4. The fact that LM cells lacked upregulation of VEGF production, (an EGFR regulatory target in most cancer cells) was interpreted as evidence that EREG functioned in paracrine signaling with endothelial cells rather than being engaged in autocrine signaling.

Although microvasculature defects do not appear to be a major component of the various EGFR-/- or other ErbB-knockout mice, studies of normal and tumor capillaries in vitro suggest signaling by family members has an influence on angiogenesis. Intriguingly, ErbB receptor expression is altered in tumor capillary endothelial cells as compared to those in normal vessels. ErbB 2, 3, 4 but minimal EGFR is found in most normal endothelial cells in culture (124). In contrast, tumor endothelial cells acquire the EGFR and down regulate ErbB3 expression both in vitro and in vivo. Endothelial cells in culture also express EGFR and ErbB4 ligands HB-EGF and NRG-1 (124-126). It is thought that HB-EGF signaling through both the EGFR and Erbb4 helps recruit pericytes to capillaries to stabilize the structures (125). The addition of exogenous EGF to tumor endothelial cells in vitro increases their proliferation (124). Shedding of HB-EGF and activation of the EGFR leads to down regulation of tight junction proteins and migration of normal endothelial cells (127). Also, NRG-1-ErbB4 signaling stimulates endothelial cell proliferation, migration and angiogenesis in animals; however, NRG-1 inhibits proliferation of tumor derived endothelial cells (124, 126). In light of the impact of EGFR signaling on tumor endothelial cells, breast cancer cell upregulation of EREG would contribute to the recruitment of a leaky vasculature that is common to aggressive tumors. In addition, EREG-EGFR/ErbB4 signaling might contribute to intrasavation and extrasavation by down regulation adhesion molecules between endothelial cells within capillaries. The question that remains is whether the low affinity ligand EREG might be more efficient at stimulating proliferation, migration and downregulation of junctional complexes than the high affinity ligand, HB-EGF normally present in endothelial cells.

\subsubsection{HB-EGF and brain metastasis}

A brain metastasis signature was derived using methods similar to those described for lung metastasis $(120,128)$. Among the genes that emerged as upregulated in brain metastatic cells was the ErbB ligand, HB-EGF (120). Treating mice cardiac-injected with brain seeking sublines MDA-MB-231 and CN34-BrM2C with cetuximab resulted in reduced numbers of brain metastases. Knockdown of both EREG and HB-EGF, or cetuximab treatment, reduced migration of MDA-MB-231 and CN34-BrM2C through consecutive monolayers of endothelial cells and astrocytes in a model of blood brain barrier extravasation. Brain endothelial cells and astrocytes both express the EGFR $(100,127)$. Activation of the EGFR has been shown to down regulate components of tight junctions in brain endothelial cells (127). This coupled with EGFR signaling induced upregulation of motility, chemokines and 
extracellular matrix remodeling genes in astrocytes would likely aid in extrasavation of breast cancer cells through the blood brain barrier into the parenchyma. Beyond this EGFR signaling produces reactive astrocytes that are components of the microenvironment of brain metastases. This raises the question of whether breast cancer generated EGFR ligands could play a role in breast cancer cell virulence in the brain by generating increased numbers of reactive astrocytes (129). HB-EGF is the EGFR ligand most abundantly expressed in the brain and endothelial cells, suggesting it may be the most well suited agonist to mediate in paracrine interactions among cancer cells, capillaries and the brain parenchyma.

\subsubsection{AREG and bone metastasis}

Tumor cell colonization of bone may be a less complex process than that of lung and brain because the capillaries in bone called sinusoids, have large openings in them to facilitate entrance of bone marrow derivatives into the circulation (119). It is thought that cancer cells may be able to exit through these openings dispensing with the intricacies of extravasation from continuous capillaries.

The growth of breast cancer macrometastases is described as a vicious cycle $(130,131)$. In this cycle, breast cancer cells exploit the natural renewal process based on the paracrine interactions between the bone forming osteoblast and the bone resorbing osteoclast. In normal bone, osteoblasts regulate osteoclast numbers and activity by releasing chemokines that recruit osteoclast precursors and then differentiate and activate them with a cell surface ligand for the receptor for activation of NFK $\beta$ (RANKL). Osteoblasts also produce a soluble decoy receptor osteoprotegrin (OPG) that prevents RANKL from engaging its receptor; therefore, the level of the ratio of OPG to RANKL controls osteoclastogenesis. Once activated, osteoclasts adhere to the bone surface and secrete proteases and acid that degrades mineralized matrix. Growth factors including TGF $\beta$ and IGF-1 are released from the bone matrix, and this in turn stimulates new bone matrix formation by osteoblasts. This is a regenerating system that is in balance within the local environment; however, the rate of turnover and formation can be modulated by a series of endocrine hormones including PTH and calcitonin. Within the bone marrow, breast cancer cells produce a series of cytokines and growth factors including IL-11 and PTH-related protein (PTHrP) that increase the levels of RANKL relative to OPG leading to increased osteoclastogenesis. The increased bone resorption and resulting high level of growth factors enhance the survival of breast cancer cells, and also TGF $\beta$ increases gene expression of IL-11 and PTHrP, which begets more osteoclasts.

Profiling bone metastasis subclones of MDA-MB-231 cells resulted in an 11-gene signature (122). Several of the genes identified were factors like IL-11 that directly altered the RANKL/OPG ratio or connective tissue factor that enhanced osteoblast proliferation. Ectopic expression of a single gene from the profile had very little impact on the ability of modestly osteolytic 231 subclones to grow within in the bone of immunocompromised mice. However, the combination of 3 of the genes from the signature induced destructive growth in bone after intracardiac injection. Among the genes identified in the signature that produced increased osteolysis when overexpressed as part of a 3 gene cassette were the proteases, MMP1 and ADAMTS-1 (12). It was unclear what the role of these molecules would play in bone metastasis. Eventually, a careful evaluation of aggressively osteolytic MDA-MB-231 lines that were engineered to overexpress ADAMTS-1 and MMP1 were found to shed dramatically increased levels of AREG. Conditioned media from the ADAMTS-1 
and MMP1 engineered MDA-MB-231 lines caused an increased RANKL/OPG ratio in primary murine bone cell cultures $(12,132)$. The conditioned media from the MDA-MB-231ADAMTS-1 and MMP1 cells activated osteoclastogenesis in the primary bone cell cultures, and this could be inhibited by the EGFR inhibitors gefitinib or cetuximab. Remarkably, these agents (Gefitinib 100mg/kg daily or Cetuximab $100 \mathrm{mg} / \mathrm{kg}$ weekly) completely prevented the formation of osteolytic lesions by the MDA-MB-231 ADAMTS-1+MMP1 line delivered by either the intracardiac or intratibial injection method (12). These findings clearly support the notion that EGFR signaling on cells of the osteoblast is a major regulator of the RANKL/OPG ratio, but point out the requirement for appropriate protease expression to make EGFR ligands accessible to the bone microenvironment. These experiments provide an explanation of how bone resorbtion could be uncoupled from bone formation by breast cancer cells because stimulation of the EGFR should block osteoblast differentiation and matrix production.

To some extent, the identification of a role for AREG in bone metastasis is confounding given that its expression is associated with $E R \alpha+$ breast cancers that generally have good prognosis (115). The MDA-MB-231 cells are ER $\alpha$ - and have a phenotype that is similar to basal cancers. So we interrogated the breast cancer transcriptome datasets GSE2034(133), GSE2603 (123), and GSE12276 (120) from the NCBI Gene Expression Omnibus to evaluate AREG expression in ER $\alpha$ - tumors. We found that AREG expression was lower in the ER $\alpha$ negative tumors that ultimately metastasized to bone as compared to those that did not (134). A similar pattern of expression has been reported for the classical bone metastasis virulence factor PTHrP. Low expression of the peptide is observed in the primary tumors that ultimately metastasize to bone (135-137). PTHrP gene expression is thought to be activated by TGF $\beta$ when breast cancer cells enter the bone microenvironment (138). In contrast to PTHrP, the enhanced activity or expression of the proteases that cleave AREG would be sufficient to increase its expression in the bone microenvironment without activating gene expression. Consistent with this concept, high expression ADAMTS-1 and MMP1 protein have been observed in primary breast cancer tumors that ultimately metastasized to bone (12). Thus, the complex post-genomic regulation of EGFR ligand processing and receptor interactions provides mechanism beyond transcription where the amplitude of signaling of this system can be increased to contribute to colonization. Given that AREG appears to be the physiological mediator of EGFR signaling in the bone, it may be ideally suited to uncouple bone formation from bone resorbtion, which is a component of osteolytic predominant bone metastases that arise from breast cancers.

\subsection{Conclusions: EGFR ligand function in breast cancer}

EGFR ligands and receptors are frequently expressed together on epithelial cells and the cancers that are derived from these tissues, including the breast. Addition of exogenous EGFR ligands to breast epithelial or cancer cells typically has a profound impact on proliferation or migratory behavior, leading to the concept that autocrine receptor signaling would contribute to tumor progression. Despite this perspective, the unraveling of the developmental breast, heart and brain phenotypes of the various family member KOs suggest that EGFR, ligand and ADAM-17 function as part of a complex paracrine-signaling network. In addition, in vitro and in vivo models based on MDA-MB-231 cells where EGFR ligands have been found to function as metastasis genes, suggest they signal in a paracrine fashion to key elements of the microenvironment. On the basis of these conclusions, we 
speculate that TGF $\alpha$ expression in primary basal breast cancers may also be engaged in paracrine signaling with cells in the microenvironment. This conclusion suggests that the efficacy of EGFR targeted therapeutics will depend upon their uses in combination with other compounds that target the tumor microenvironment in primary basal tumors, as well as those that have metastasized to the lung, brain and bone.

\section{References}

[1] Llombart-Cussac A. Improving decision-making in early breast cancer: who to treat and how? Breast Cancer Res Treat2008 Dec;112 Suppl 1:15-24.

[2] Brufsky A. Trastuzumab-based therapy for patients with HER2-positive breast cancer: from early scientific development to foundation of care. Am J Clin Oncol2010 Apr;33(2):186-95.

[3] Yarden Y, Sliwkowski MX. Untangling the ErbB signalling network. Nat Rev Mol Cell Biol2001 Feb;2(2):127-37.

[4] Wilson KJ, Gilmore JL, Foley J, Lemmon MA, Riese DJ, 2nd. Functional selectivity of EGF family peptide growth factors: implications for cancer. Pharmacol Ther2009 Apr;122(1):1-8.

[5] Daub H, Weiss FU, Wallasch C, Ullrich A. Role of transactivation of the EGF receptor in signalling by G-protein-coupled receptors. Nature1996 Feb 8;379(6565):557-60.

[6] Iwamoto R, Mekada E. Heparin-binding EGF-like growth factor: a juxtacrine growth factor. Cytokine Growth Factor Rev2000 Dec;11(4):335-44.

[7] Prince RN, Schreiter ER, Zou P, Wiley HS, Ting AY, Lee RT, Lauffenburger DA. The heparin-binding domain of HB-EGF mediates localization to sites of cell-cell contact and prevents HB-EGF proteolytic release. J Cell Sci2010 Jul 1;123(Pt 13):2308-18.

[8] Sahin U, Weskamp G, Kelly K, Zhou HM, Higashiyama S, Peschon J, Hartmann D, Saftig $\mathrm{P}$, Blobel CP. Distinct roles for ADAM10 and ADAM17 in ectodomain shedding of six EGFR ligands. J Cell Biol2004 Mar 1;164(5):769-79.

[9] Tousseyn T, Jorissen E, Reiss K, Hartmann D. (Make) stick and cut loose--disintegrin metalloproteases in development and disease. Birth Defects Res C Embryo Today2006 Mar;78(1):24-46.

[10] Zhang Q, Thomas SM, Lui VW, Xi S, Siegfried JM, Fan H, Smithgall TE, Mills GB, Grandis JR. Phosphorylation of TNF-alpha converting enzyme by gastrin-releasing peptide induces amphiregulin release and EGF receptor activation. Proc Natl Acad Sci U S A2006 May 2;103(18):6901-6.

[11] Wagstaff L, Kelwick R, Decock J, Edwards DR. The roles of ADAMTS metalloproteinases in tumorigenesis and metastasis. Front Biosci2011;16:1861-72.

[12] Lu X, Wang Q, Hu G, Van Poznak C, Fleisher M, Reiss M, Massague J, Kang Y. ADAMTS1 and MMP1 proteolytically engage EGF-like ligands in an osteolytic signaling cascade for bone metastasis. Genes Dev2009 Aug 15;23(16):1882-94.

[13] Chokki M, Eguchi H, Hamamura I, Mitsuhashi H, Kamimura T. Human airway trypsin-like protease induces amphiregulin release through a mechanism involving protease-activated receptor-2-mediated ERK activation and TNF alpha-converting enzyme activity in airway epithelial cells. Febs J2005 Dec;272(24):6387-99. 
[14] Pawlowski V, Revillion F, Hebbar M, Hornez L, Peyrat JP. Prognostic value of the type I growth factor receptors in a large series of human primary breast cancers quantified with a real-time reverse transcription-polymerase chain reaction assay. Clin Cancer Res2000 Nov;6(11):4217-25.

[15] McIntyre E, Blackburn E, Brown PJ, Johnson CG, Gullick WJ. The complete family of epidermal growth factor receptors and their ligands are co-ordinately expressed in breast cancer. Breast Cancer Res Treat2010 Jul;122(1):105-10.

[16] Revillion F, Lhotellier V, Hornez L, Bonneterre J, Peyrat JP. ErbB/HER ligands in human breast cancer, and relationships with their receptors, the bio-pathological features and prognosis. Ann Oncol2008 Jan;19(1):73-80.

[17] Edwin F, Wiepz GJ, Singh R, Peet CR, Chaturvedi D, Bertics PJ, Patel TB. A historical perspective of the EGF receptor and related systems. Methods Mol Biol2006;327:124.

[18] Riese DJ, 2nd, Stern DF. Specificity within the EGF family/ErbB receptor family signaling network. Bioessays1998 Jan;20(1):41-8.

[19] Lemmon MA. Ligand-induced ErbB receptor dimerization. Exp Cell Res2009 Feb 15;315(4):638-48.

[20] Riese DJ, 2nd, Gallo RM, Settleman J. Mutational activation of ErbB family receptor tyrosine kinases: insights into mechanisms of signal transduction and tumorigenesis. Bioessays2007 Jun;29(6):558-65.

[21] Schulze WX, Deng L, Mann M. Phosphotyrosine interactome of the ErbB-receptor kinase family. Mol Syst Biol2005;1:2005 0008.

[22] Roepstorff K, Grandal MV, Henriksen L, Knudsen SL, Lerdrup M, Grovdal L, Willumsen BM, van Deurs B. Differential effects of EGFR ligands on endocytic sorting of the receptor. Traffic2009 Aug;10(8):1115-27.

[23] Avraham R, Yarden Y. Feedback regulation of EGFR signalling: decision making by early and delayed loops. Nat Rev Mol Cell Biol2011 Feb;12(2):104-17.

[24] Bublil EM, Yarden Y. The EGF receptor family: spearheading a merger of signaling and therapeutics. Curr Opin Cell Biol2007 Apr;19(2):124-34.

[25] Citri A, Yarden Y. EGF-ERBB signalling: towards the systems level. Nat Rev Mol Cell Biol2006 Jul;7(7):505-16.

[26] Slamon DJ, Clark GM, Wong SG, Levin WJ, Ullrich A, McGuire WL. Human breast cancer: correlation of relapse and survival with amplification of the HER-2/neu oncogene. Science1987 Jan 9;235(4785):177-82.

[27] Salomon DS, Brandt R, Ciardiello F, Normanno N. Epidermal growth factor-related peptides and their receptors in human malignancies. Crit Rev Oncol Hematol1995 Jul;19(3):183-232.

[28] Earp HS, Dawson TL, Li X, Yu H. Heterodimerization and functional interaction between EGF receptor family members: a new signaling paradigm with implications for breast cancer research. Breast Cancer Res Treat1995 Jul;35(1):11532.

[29] Wada T, Qian XL, Greene MI. Intermolecular association of the p185neu protein and EGF receptor modulates EGF receptor function. Cell1990 Jun 29;61(7):1339-47. 
[30] Wang Z, Zhang L, Yeung TK, Chen X. Endocytosis deficiency of epidermal growth factor (EGF) receptor-ErbB2 heterodimers in response to EGF stimulation. Mol Biol Cell1999 May;10(5):1621-36.

[31] Hendriks BS, Wiley HS, Lauffenburger D. HER2-mediated effects on EGFR endosomal sorting: analysis of biophysical mechanisms. Biophys J2003 Oct;85(4):2732-45.

[32] Jones JT, Akita RW, Sliwkowski MX. Binding specificities and affinities of egf domains for ErbB receptors. FEBS Lett1999 Mar 26;447(2-3):227-31.

[33] Liu W, Volpe MA, Zscheppang K, Nielsen HC, Dammann CE. ErbB4 regulates surfactant synthesis and proliferation in adult rat pulmonary epithelial cells. Exp Lung Res2009 Feb;35(1):29-47.

[34] Zscheppang K, Korenbaum E, Bueter W, Ramadurai SM, Nielsen HC, Dammann CE. ErbB receptor dimerization, localization, and co-localization in mouse lung type II epithelial cells. Pediatr Pulmonol2006 Dec;41(12):1205-12.

[35] Hatakeyama M, Yumoto N, Yu X, Shirouzu M, Yokoyama S, Konagaya A. Transformation potency of ErbB heterodimer signaling is determined by B-Raf kinase. Oncogene2004 Jun 24;23(29):5023-31.

[36] Frolov A, Schuller K, Tzeng CW, Cannon EE, Ku BC, Howard JH, Vickers SM, Heslin MJ, Buchsbaum DJ, Arnoletti JP. ErbB3 expression and dimerization with EGFR influence pancreatic cancer cell sensitivity to erlotinib. Cancer Biol Ther2007 Apr;6(4):548-54.

[37] Liles JS, Arnoletti JP, Tzeng CW, Howard JH, Kossenkov AV, Kulesza P, Heslin MJ, Frolov A. ErbB3 expression promotes tumorigenesis in pancreatic adenocarcinoma. Cancer Biol Ther2010 Sep;10(6):555-63.

[38] Waterman H, Sabanai I, Geiger B, Yarden Y. Alternative intracellular routing of ErbB receptors may determine signaling potency. J Biol Chem1998 May 29;273(22):1381927.

[39] French AR, Sudlow GP, Wiley HS, Lauffenburger DA. Postendocytic trafficking of epidermal growth factor-receptor complexes is mediated through saturable and specific endosomal interactions. J Biol Chem1994 Jun 3;269(22):15749-55.

[40] Reddy CC, Niyogi SK, Wells A, Wiley HS, Lauffenburger DA. Engineering epidermal growth factor for enhanced mitogenic potency. Nat Biotechnol1996 Dec;14(13):1696-9.

[41] Willmarth NE, Ethier SP. Autocrine and juxtacrine effects of amphiregulin on the proliferative, invasive, and migratory properties of normal and neoplastic human mammary epithelial cells. J Biol Chem2006 Dec 8;281(49):37728-37.

[42] Streicher KL, Willmarth NE, Garcia J, Boerner JL, Dewey TG, Ethier SP. Activation of a nuclear factor kappaB/interleukin-1 positive feedback loop by amphiregulin in human breast cancer cells. Mol Cancer Res2007 Aug;5(8):847-61.

[43] Willmarth NE, Baillo A, Dziubinski ML, Wilson K, Riese DJ, 2nd, Ethier SP. Altered EGFR localization and degradation in human breast cancer cells with an amphiregulin/EGFR autocrine loop. Cell Signal2009 Feb;21(2):212-9.

[44] Shoyab M, McDonald VL, Bradley JG, Todaro GJ. Amphiregulin: a bifunctional growth-modulating glycoprotein produced by the phorbol 12-myristate 13-acetate- 
treated human breast adenocarcinoma cell line MCF-7. Proc Natl Acad Sci U S A1988 Sep;85(17):6528-32.

[45] Shoyab M, Plowman GD, McDonald VL, Bradley JG, Todaro GJ. Structure and function of human amphiregulin: a member of the epidermal growth factor family. Science1989 Feb 24;243(4894 Pt 1):1074-6.

[46] Stoll SW, Johnson JL, Bhasin A, Johnston A, Gudjonsson JE, Rittie L, Elder JT. Metalloproteinase-mediated, context-dependent function of amphiregulin and HBEGF in human keratinocytes and skin. J Invest Dermatol2010 Jan;130(1):295-304.

[47] Barnard JA, Graves-Deal R, Pittelkow MR, DuBois R, Cook P, Ramsey GW, Bishop PR, Damstrup L, Coffey RJ. Auto- and cross-induction within the mammalian epidermal growth factor-related peptide family. J Biol Chem1994 Sep 9;269(36):22817-22.

[48] Cook PW, Mattox PA, Keeble WW, Pittelkow MR, Plowman GD, Shoyab M, Adelman JP, Shipley GD. A heparin sulfate-regulated human keratinocyte autocrine factor is similar or identical to amphiregulin. Mol Cell Biol1991 May;11(5):2547-57.

[49] Neelam B, Richter A, Chamberlin SG, Puddicombe SM, Wood L, Murray MB, Nandagopal K, Niyogi SK, Davies DE. Structure-function studies of ligand-induced epidermal growth factor receptor dimerization. Biochemistry1998 Apr 7;37(14):4884-91.

[50] Adam R, Drummond DR, Solic N, Holt SJ, Sharma RP, Chamberlin SG, Davies DE. Modulation of the receptor binding affinity of amphiregulin by modification of its carboxyl terminal tail. Biochim Biophys Acta1995 Apr 6;1266(1):83-90.

[51] Gilmore JL, Scott JA, Bouizar Z, Robling A, Pitfield SE, Riese DJ, 2nd, Foley J. Amphiregulin-EGFR signaling regulates PTHrP gene expression in breast cancer cells. Breast Cancer Res Treat2007 Sep 20.

[52] Stern KA, Place TL, Lill NL. EGF and amphiregulin differentially regulate $\mathrm{Cbl}$ recruitment to endosomes and EGF receptor fate. Biochem J2008 Mar 15;410(3):58594.

[53] Chung E, Graves-Deal R, Franklin JL, Coffey RJ. Differential effects of amphiregulin and TGF-alpha on the morphology of MDCK cells. Exp Cell Res2005 Sep 10;309(1):149-60.

[54] Kochupurakkal BS, Harari D, Di-Segni A, Maik-Rachline G, Lyass L, Gur G, Kerber G, Citri A, Lavi S, Eilam R, Chalifa-Caspi V, Eshhar Z, Pikarsky E, Pinkas-Kramarski R, Bacus SS, Yarden Y. Epigen, the last ligand of ErbB receptors, reveals intricate relationships between affinity and mitogenicity. J Biol Chem2005 Mar 4;280(9):850312.

[55] Strachan L, Murison JG, Prestidge RL, Sleeman MA, Watson JD, Kumble KD. Cloning and biological activity of epigen, a novel member of the epidermal growth factor superfamily. J Biol Chem2001 May 25;276(21):18265-71.

[56] Elenius K, Paul S, Allison G, Sun J, Klagsbrun M. Activation of HER4 by heparinbinding EGF-like growth factor stimulates chemotaxis but not proliferation. Embo J1997 Mar 17;16(6):1268-78. 
[57] Higashiyama S, Abraham JA, Miller J, Fiddes JC, Klagsbrun M. A heparin-binding growth factor secreted by macrophage-like cells that is related to EGF. Science1991 Feb 22;251(4996):936-9.

[58] Nishi E, Klagsbrun M. Heparin-binding epidermal growth factor-like growth factor (HB-EGF) is a mediator of multiple physiological and pathological pathways. Growth Factors2004 Dec;22(4):253-60.

[59] Shing Y, Christofori G, Hanahan D, Ono Y, Sasada R, Igarashi K, Folkman J. Betacellulin: a mitogen from pancreatic beta cell tumors. Science1993 Mar 12;259(5101):1604-7.

[60] Sweeney C, Lai C, Riese DJ, 2nd, Diamonti AJ, Cantley LC, Carraway KL, 3rd. Ligand discrimination in signaling through an ErbB4 receptor homodimer. J Biol Chem2000 Jun 30;275(26):19803-7.

[61] Tada H, Sasada R, Kawaguchi Y, Kojima I, Gullick WJ, Salomon DS, Igarashi K, Seno M, Yamada H. Processing and juxtacrine activity of membrane-anchored betacellulin. J Cell Biochem1999 Mar 1;72(3):423-34.

[62] Komurasaki T, Toyoda H, Uchida D, Morimoto S. Epiregulin binds to epidermal growth factor receptor and ErbB-4 and induces tyrosine phosphorylation of epidermal growth factor receptor, ErbB-2, ErbB-3 and ErbB-4. Oncogene1997 Dec 4;15(23):2841-8.

[63] Sasaki E, Arakawa T, Fujiwara Y, Kawada N, Fukuda T, Higuchi K, Komurasaki T, Kobayashi K. Epiregulin stimulates proliferation of rabbit gastric cells in primary culture through autophosphorylation of the epidermal growth factor receptor. Eur J Pharmacol1997 Nov 12;338(3):253-8.

[64] Riese DJ, 2nd, Komurasaki T, Plowman GD, Stern DF. Activation of ErbB4 by the bifunctional epidermal growth factor family hormone epiregulin is regulated by ErbB2. J Biol Chem1998 May 1;273(18):11288-94.

[65] Shelly M, Pinkas-Kramarski R, Guarino BC, Waterman H, Wang LM, Lyass L, Alimandi M, Kuo A, Bacus SS, Pierce JH, Andrews GC, Yarden Y. Epiregulin is a potent pan-ErbB ligand that preferentially activates heterodimeric receptor complexes. J Biol Chem1998 Apr 24;273(17):10496-505.

[66] Cardiff RD, Wellings SR. The comparative pathology of human and mouse mammary glands. J Mammary Gland Biol Neoplasia1999 Jan;4(1):105-22.

[67] Hens JR, Wysolmerski JJ. Key stages of mammary gland development: molecular mechanisms involved in the formation of the embryonic mammary gland. Breast Cancer Res2005;7(5):220-4.

[68] Fendrick JL, Raafat AM, Haslam SZ. Mammary gland growth and development from the postnatal period to postmenopause: ovarian steroid receptor ontogeny and regulation in the mouse. J Mammary Gland Biol Neoplasia1998 Jan;3(1):7-22.

[69] Nandi S. Endocrine control of mammarygland development and function in the $\mathrm{C} 3 \mathrm{H} /$ He Crgl mouse. J Natl Cancer Inst1958 Dec;21(6):1039-63.

[70] Snedeker SM, Brown CF, DiAugustine RP. Expression and functional properties of transforming growth factor alpha and epidermal growth factor during mouse mammary gland ductal morphogenesis. Proc Natl Acad Sci U S A1991 Jan 1;88(1):276-80. 
[71] Watson CJ, Khaled WT. Mammary development in the embryo and adult: a journey of morphogenesis and commitment. Development2008 Mar;135(6):995-1003.

[72] Brisken C, Kaur S, Chavarria TE, Binart N, Sutherland RL, Weinberg RA, Kelly PA, Ormandy CJ. Prolactin controls mammary gland development via direct and indirect mechanisms. Dev Biol1999 Jun 1;210(1):96-106.

[73] Brisken C, Park S, Vass T, Lydon JP, O'Malley BW, Weinberg RA. A paracrine role for the epithelial progesterone receptor in mammary gland development. Proc Natl Acad Sci U S A1998 Apr 28;95(9):5076-81.

[74] Schroeder JA, Lee DC. Dynamic expression and activation of ERBB receptors in the developing mouse mammary gland. Cell Growth Differ1998 Jun;9(6):451-64.

[75] Sebastian J, Richards RG, Walker MP, Wiesen JF, Werb Z, Derynck R, Hom YK, Cunha GR, DiAugustine RP. Activation and function of the epidermal growth factor receptor and erbB-2 during mammary gland morphogenesis. Cell Growth Differ1998 Sep;9(9):777-85.

[76] Wiesen JF, Young P, Werb Z, Cunha GR. Signaling through the stromal epidermal growth factor receptor is necessary for mammary ductal development. Development1999 Jan;126(2):335-44.

[77] Kenney NJ, Huang RP, Johnson GR, Wu JX, Okamura D, Matheny W, Kordon E, Gullick WJ, Plowman G, Smith GH, et al. Detection and location of amphiregulin and Cripto-1 expression in the developing postnatal mouse mammary gland. Mol Reprod Dev1995 Jul;41(3):277-86.

[78] Luetteke NC, Qiu TH, Fenton SE, Troyer KL, Riedel RF, Chang A, Lee DC. Targeted inactivation of the EGF and amphiregulin genes reveals distinct roles for EGF receptor ligands in mouse mammary gland development. Development1999 Jun;126(12):2739-50.

[79] Ciarloni L, Mallepell S, Brisken C. Amphiregulin is an essential mediator of estrogen receptor alpha function in mammary gland development. Proc Natl Acad Sci U S A2007 Mar 27;104(13):5455-60.

[80] Rho JY, Wada-Kiyama Y, Onishi Y, Kiyama R, Sakuma Y. Expressional regulation of neuronal and cancer-related genes by estrogen in adult female rats. Endocr Res2004 May;30(2):257-67.

[81] Britton DJ, Hutcheson IR, Knowlden JM, Barrow D, Giles M, McClelland RA, Gee JM, Nicholson RI. Bidirectional cross talk between ERalpha and EGFR signalling pathways regulates tamoxifen-resistant growth. Breast Cancer Res Treat2006 Mar;96(2):131-46.

[82] Sternlicht MD, Sunnarborg SW, Kouros-Mehr H, Yu Y, Lee DC, Werb Z. Mammary ductal morphogenesis requires paracrine activation of stromal EGFR via ADAM17dependent shedding of epithelial amphiregulin. Development2005 Sep;132(17):3923-33.

[83] Asselin-Labat ML, Vaillant F, Shackleton M, Bouras T, Lindeman GJ, Visvader JE. Delineating the epithelial hierarchy in the mouse mammary gland. Cold Spring Harb Symp Quant Biol2008;73:469-78. 
[84] Eirew P, Stingl J, Raouf A, Turashvili G, Aparicio S, Emerman JT, Eaves CJ. A method for quantifying normal human mammary epithelial stem cells with in vivo regenerative ability. Nat Med2008 Dec;14(12):1384-9.

[85] Lim E, Vaillant F, Wu D, Forrest NC, Pal B, Hart AH, Asselin-Labat ML, Gyorki DE, Ward T, Partanen A, Feleppa F, Huschtscha LI, Thorne HJ, Fox SB, Yan M, French JD, Brown MA, Smyth GK, Visvader JE, Lindeman GJ. Aberrant luminal progenitors as the candidate target population for basal tumor development in BRCA1 mutation carriers. Nat Med2009 Aug;15(8):907-13.

[86] Asselin-Labat ML, Sutherland KD, Barker H, Thomas R, Shackleton M, Forrest NC, Hartley L, Robb L, Grosveld FG, van der Wees J, Lindeman GJ, Visvader JE. Gata-3 is an essential regulator of mammary-gland morphogenesis and luminal-cell differentiation. Nat Cell Biol2007 Feb;9(2):201-9.

[87] Jackson-Fisher AJ, Bellinger G, Breindel JL, Tavassoli FA, Booth CJ, Duong JK, Stern DF. ErbB3 is required for ductal morphogenesis in the mouse mammary gland. Breast Cancer Res2008;10(6):R96.

[88] Jackson-Fisher AJ, Bellinger G, Ramabhadran R, Morris JK, Lee KF, Stern DF. ErbB2 is required for ductal morphogenesis of the mammary gland. Proc Natl Acad Sci U S A2004 Dec 7;101(49):17138-43.

[89] Tidcombe H, Jackson-Fisher A, Mathers K, Stern DF, Gassmann M, Golding JP. Neural and mammary gland defects in ErbB4 knockout mice genetically rescued from embryonic lethality. Proc Natl Acad Sci U S A2003 Jul 8;100(14):8281-6.

[90] Lee KF, Simon H, Chen H, Bates B, Hung MC, Hauser C. Requirement for neuregulin receptor erbB2 in neural and cardiac development. Nature1995 Nov 23;378(6555):394-8.

[91] Erickson SL, O'Shea KS, Ghaboosi N, Loverro L, Frantz G, Bauer M, Lu LH, Moore MW. ErbB3 is required for normal cerebellar and cardiac development: a comparison with ErbB2-and heregulin-deficient mice. Development1997 Dec;124(24):4999-5011.

[92] Kramer R, Bucay N, Kane DJ, Martin LE, Tarpley JE, Theill LE. Neuregulins with an Iglike domain are essential for mouse myocardial and neuronal development. Proc Natl Acad Sci U S A1996 May 14;93(10):4833-8.

[93] Gassmann M, Casagranda F, Orioli D, Simon H, Lai C, Klein R, Lemke G. Aberrant neural and cardiac development in mice lacking the ErbB4 neuregulin receptor. Nature1995 Nov 23;378(6555):390-4.

[94] Sanchez-Soria P, Camenisch TD. ErbB signaling in cardiac development and disease. Semin Cell Dev Biol2010 Dec;21(9):929-35.

[95] Schroeder JA, Jackson LF, Lee DC, Camenisch TD. Form and function of developing heart valves: coordination by extracellular matrix and growth factor signaling. J Mol Med2003 Jul;81(7):392-403.

[96] Sibilia M, Wagner EF. Strain-dependent epithelial defects in mice lacking the EGF receptor. Science1995 Jul 14;269(5221):234-8.

[97] Jackson LF, Qiu TH, Sunnarborg SW, Chang A, Zhang C, Patterson C, Lee DC. Defective valvulogenesis in HB-EGF and TACE-null mice is associated with aberrant BMP signaling. Embo J2003 Jun 2;22(11):2704-16. 
[98] Kornblum HI, Hussain R, Wiesen J, Miettinen P, Zurcher SD, Chow K, Derynck R, Werb Z. Abnormal astrocyte development and neuronal death in mice lacking the epidermal growth factor receptor. J Neurosci Res1998 Sep 15;53(6):697-717.

[99] Kornblum HI, Zurcher SD, Werb Z, Derynck R, Seroogy KB. Multiple trophic actions of heparin-binding epidermal growth factor (HB-EGF) in the central nervous system. Eur J Neurosci1999 Sep;11(9):3236-46.

[100] Kornblum HI, Hussain RJ, Bronstein JM, Gall CM, Lee DC, Seroogy KB. Prenatal ontogeny of the epidermal growth factor receptor and its ligand, transforming growth factor alpha, in the rat brain. J Comp Neurol1997 Apr 7;380(2):243-61.

[101] Liu B, Neufeld AH. Activation of epidermal growth factor receptors in astrocytes: from development to neural injury. J Neurosci Res2007 Dec;85(16):3523-9.

[102] Kang W, Hebert JM. Signaling pathways in reactive astrocytes, a genetic perspective. Mol Neurobiol2011 Jun;43(3):147-54.

[103] Ibbotson KJ, D'Souza SM, Ng KW, Osborne CK, Niall M, Martin TJ, Mundy GR. Tumor-derived growth factor increases bone resorption in a tumor associated with humoral hypercalcemia of malignancy. Science1983 Sep 23;221(4617):1292-4.

[104] Ibbotson KJ, D'Souza SM, Smith DD, Carpenter G, Mundy GR. EGF receptor antiserum inhibits bone resorbing activity produced by a rat Leydig cell tumor associated with the humoral hypercalcemia of malignancy. Endocrinology1985 Jan;116(1):469-71.

[105] Shupnik MA, Ip NY, Tashjian AH, Jr. Characterization and regulation of receptors for epidermal growth factor in mouse calvaria. Endocrinology1980 Dec;107(6):1738-46.

[106] Sibilia M, Wagner B, Hoebertz A, Elliott C, Marino S, Jochum W, Wagner EF. Mice humanised for the EGF receptor display hypomorphic phenotypes in skin, bone and heart. Development2003 Oct;130(19):4515-25.

[107] Qin L, Partridge NC. Stimulation of amphiregulin expression in osteoblastic cells by parathyroid hormone requires the protein kinase A and cAMP response elementbinding protein signaling pathway. J Cell Biochem2005 Oct 15;96(3):632-40.

[108] Qin L, Qiu P, Wang L, Li X, Swarthout JT, Soteropoulos P, Tolias P, Partridge NC. Gene expression profiles and transcription factors involved in parathyroid hormone signaling in osteoblasts revealed by microarray and bioinformatics. J Biol Chem2003 May 30;278(22):19723-31.

[109] Cole JA. Parathyroid hormone activates mitogen-activated protein kinase in opossum kidney cells. Endocrinology1999 Dec;140(12):5771-9.

[110] van 't Veer LJ, Dai H, van de Vijver MJ, He YD, Hart AA, Mao M, Peterse HL, van der Kooy K, Marton MJ, Witteveen AT, Schreiber GJ, Kerkhoven RM, Roberts C, Linsley PS, Bernards R, Friend SH. Gene expression profiling predicts clinical outcome of breast cancer. Nature2002 Jan 31;415(6871):530-6.

[111] van de Vijver MJ, He YD, van't Veer LJ, Dai H, Hart AA, Voskuil DW, Schreiber GJ, Peterse JL, Roberts C, Marton MJ, Parrish M, Atsma D, Witteveen A, Glas A, Delahaye L, van der Velde T, Bartelink H, Rodenhuis S, Rutgers ET, Friend SH, Bernards R. A gene-expression signature as a predictor of survival in breast cancer. N Engl J Med2002 Dec 19;347(25):1999-2009. 
[112] Sorlie T, Perou CM, Tibshirani R, Aas T, Geisler S, Johnsen H, Hastie T, Eisen MB, van de Rijn M, Jeffrey SS, Thorsen T, Quist H, Matese JC, Brown PO, Botstein D, Eystein Lonning $\mathrm{P}$, Borresen-Dale AL. Gene expression patterns of breast carcinomas distinguish tumor subclasses with clinical implications. Proc Natl Acad Sci U S A2001 Sep 11;98(19):10869-74.

[113] Wiseman SM, Makretsov N, Nielsen TO, Gilks B, Yorida E, Cheang M, Turbin D, Gelmon K, Huntsman DG. Coexpression of the type 1 growth factor receptor family members HER-1, HER-2, and HER-3 has a synergistic negative prognostic effect on breast carcinoma survival. Cancer2005 May 1;103(9):1770-7.

[114] Zhu Y, Sullivan LL, Nair SS, Williams CC, Pandey AK, Marrero L, Vadlamudi RK, Jones FE. Coregulation of estrogen receptor by ERBB4/HER4 establishes a growthpromoting autocrine signal in breast tumor cells. Cancer Res2006 Aug 15;66(16):7991-8.

[115] McGowan PM, McKiernan E, Bolster F, Ryan BM, Hill AD, McDermott EW, Evoy D, O'Higgins N, Crown J, Duffy MJ. ADAM-17 predicts adverse outcome in patients with breast cancer. Ann Oncol2008 Jun;19(6):1075-81.

[116] Burness ML, Grushko TA, Olopade OI. Epidermal growth factor receptor in triplenegative and basal-like breast cancer: promising clinical target or only a marker? Cancer J2010 Jan-Feb;16(1):23-32.

[117] Viale G, Rotmensz N, Maisonneuve P, Bottiglieri L, Montagna E, Luini A, Veronesi P, Intra M, Torrisi R, Cardillo A, Campagnoli E, Goldhirsch A, Colleoni M. Invasive ductal carcinoma of the breast with the "triple-negative" phenotype: prognostic implications of EGFR immunoreactivity. Breast Cancer Res Treat2009 Jul;116(2):317-28.

[118] Chaffer CL, Weinberg RA. A perspective on cancer cell metastasis. Science2011 Mar 25;331(6024):1559-64.

[119] Nguyen DX, Bos PD, Massague J. Metastasis: from dissemination to organ-specific colonization. Nat Rev Cancer2009 Apr;9(4):274-84.

[120] Bos PD, Zhang XH, Nadal C, Shu W, Gomis RR, Nguyen DX, Minn AJ, van de Vijver MJ, Gerald WL, Foekens JA, Massague J. Genes that mediate breast cancer metastasis to the brain. Nature2009 Jun 18;459(7249):1005-9.

[121] Gupta GP, Nguyen DX, Chiang AC, Bos PD, Kim JY, Nadal C, Gomis RR, ManovaTodorova K, Massague J. Mediators of vascular remodelling co-opted for sequential steps in lung metastasis. Nature2007 Apr 12;446(7137):765-70.

[122] Kang Y, Siegel PM, Shu W, Drobnjak M, Kakonen SM, Cordon-Cardo C, Guise TA, Massague J. A multigenic program mediating breast cancer metastasis to bone. Cancer Cell2003 Jun;3(6):537-49.

[123] Minn AJ, Gupta GP, Siegel PM, Bos PD, Shu W, Giri DD, Viale A, Olshen AB, Gerald WL, Massague J. Genes that mediate breast cancer metastasis to lung. Nature2005 Jul 28;436(7050):518-24.

[124] Amin DN, Hida K, Bielenberg DR, Klagsbrun M. Tumor endothelial cells express epidermal growth factor receptor (EGFR) but not ErbB3 and are responsive to EGF and to EGFR kinase inhibitors. Cancer Res2006 Feb 15;66(4):2173-80. 
[125] Iivanainen E, Nelimarkka L, Elenius V, Heikkinen SM, Junttila TT, Sihombing L, Sundvall M, Maatta JA, Laine VJ, Yla-Herttuala S, Higashiyama S, Alitalo K, Elenius K. Angiopoietin-regulated recruitment of vascular smooth muscle cells by endothelial-derived heparin binding EGF-like growth factor. FASEB J2003 Sep;17(12):1609-21.

[126] Russell KS, Stern DF, Polverini PJ, Bender JR. Neuregulin activation of ErbB receptors in vascular endothelium leads to angiogenesis. Am J Physiol1999 Dec;277(6 Pt 2):H2205-11.

[127] Chen F, Hori T, Ohashi N, Baine AM, Eckman CB, Nguyen JH. Occludin is regulated by epidermal growth factor receptor activation in brain endothelial cells and brains of mice with acute liver failure. Hepatology2011 Apr;53(4):1294-305.

[128] Yoneda T, Williams PJ, Hiraga T, Niewolna M, Nishimura R. A bone-seeking clone exhibits different biological properties from the MDA-MB-231 parental human breast cancer cells and a brain-seeking clone in vivo and in vitro. J Bone Miner Res2001 Aug;16(8):1486-95.

[129] Fitzgerald DP, Palmieri D, Hua E, Hargrave E, Herring JM, Qian Y, Vega-Valle E, Weil RJ, Stark AM, Vortmeyer AO, Steeg PS. Reactive glia are recruited by highly proliferative brain metastases of breast cancer and promote tumor cell colonization. Clin Exp Metastasis2008;25(7):799-810.

[130] Guise TA, Mohammad KS, Clines G, Stebbins EG, Wong DH, Higgins LS, Vessella R, Corey E, Padalecki S, Suva L, Chirgwin JM. Basic mechanisms responsible for osteolytic and osteoblastic bone metastases. Clin Cancer Res2006 Oct 15;12(20 Pt 2):6213s-6s.

[131] Guise TA, Mundy GR. Cancer and bone. Endocr Rev1998 Feb;19(1):18-54.

[132] Zhu J, Jia X, Xiao G, Kang Y, Partridge NC, Qin L. EGF-like ligands stimulate osteoclastogenesis by regulating expression of osteoclast regulatory factors by osteoblasts: implications for osteolytic bone metastases. J Biol Chem2007 Sep 14;282(37):26656-64.

[133] Wang Y, Klijn JG, Zhang Y, Sieuwerts AM, Look MP, Yang F, Talantov D, Timmermans M, Meijer-van Gelder ME, Yu J, Jatkoe T, Berns EM, Atkins D, Foekens JA. Gene-expression profiles to predict distant metastasis of lymph-nodenegative primary breast cancer. Lancet2005 Feb 19-25;365(9460):671-9.

[134] Foley J, Nickerson NK, Nam S, Allen KT, Gilmore JL, Nephew KP, Riese DJ, 2nd. EGFR signaling in breast cancer: bad to the bone. Semin Cell Dev Biol2010 Dec;21(9):951-60.

[135] Henderson M, Danks J, Moseley J, Slavin J, Harris T, McKinlay M, Hopper J, Martin T. Parathyroid hormone-related protein production by breast cancers, improved survival, and reduced bone metastases. J Natl Cancer Inst2001 Feb 7;93(3):234-7.

[136] Powell GJ, Southby J, Danks JA, Stillwell RG, Hayman JA, Henderson MA, Bennett RC, Martin TJ. Localization of parathyroid hormone-related protein in breast cancer metastases: increased incidence in bone compared with other sites. Cancer Res1991 Jun 1;51(11):3059-61. 
[137] Southby J, Kissin MW, Danks JA, Hayman JA, Moseley JM, Henderson MA, Bennett RC, Martin TJ. Immunohistochemical localization of parathyroid hormone-related protein in human breast cancer. Cancer Res1990 Dec 1;50(23):7710-6.

[138] Yin JJ, Selander K, Chirgwin JM, Dallas M, Grubbs BG, Wieser R, Massague J, Mundy GR, Guise TA. TGF-beta signaling blockade inhibits PTHrP secretion by breast cancer cells and bone metastases development. J Clin Invest1999 Jan;103(2):197-206. 


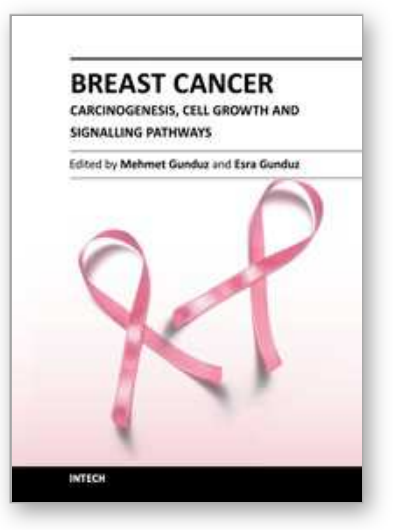

\author{
Breast Cancer - Carcinogenesis, Cell Growth and Signalling \\ Pathways \\ Edited by Prof. Mehmet Gunduz
}

ISBN 978-953-307-714-7

Hard cover, 732 pages

Publisher InTech

Published online 30, November, 2011

Published in print edition November, 2011

Cancer is the leading cause of death in most countries and its consequences result in huge economic, social and psychological burden. Breast cancer is the most frequently diagnosed cancer type and the leading cause of cancer death among females. In this book, we discussed various aspects of breast cancer carcinogenesis from clinics to its hormone-based as well as genetic-based etiologies for this deadly cancer. We hope that this book will contribute to the development of novel diagnostic as well as therapeutic approaches.

\title{
How to reference
}

In order to correctly reference this scholarly work, feel free to copy and paste the following:

Nicole K. Nickerson, Jennifer L. Gilmore, Kah Tan Allen, David J. Riese II, Kenneth P. Nephew and John Foley (2011). EGFR-Ligand Signaling in Breast Cancer Metastasis: Recurring Developmental Themes, Breast Cancer - Carcinogenesis, Cell Growth and Signalling Pathways, Prof. Mehmet Gunduz (Ed.), ISBN: 978-953307-714-7, InTech, Available from: http://www.intechopen.com/books/breast-cancer-carcinogenesis-cellgrowth-and-signalling-pathways/egfr-ligand-signaling-in-breast-cancer-metastasis-recurring-developmentalthemes

\section{INTECH}

open science | open minds

\section{InTech Europe}

University Campus STeP Ri Slavka Krautzeka 83/A 51000 Rijeka, Croatia Phone: +385 (51) 770447

Fax: +385 (51) 686166 www.intechopen.com

\section{InTech China}

Unit 405, Office Block, Hotel Equatorial Shanghai No.65, Yan An Road (West), Shanghai, 200040, China 中国上海市延安西路65号上海国际贵都大饭店办公楼405单元 Phone: +86-21-62489820

Fax: +86-21-62489821 
(C) 2011 The Author(s). Licensee IntechOpen. This is an open access article distributed under the terms of the Creative Commons Attribution 3.0 License, which permits unrestricted use, distribution, and reproduction in any medium, provided the original work is properly cited. 